\title{
Te Arewhana Kei Roto i Te Rūma: An Indigenous Neo-Disputatio on Settler Society, Nullifying Te Tiriti, 'Natural Resources' and Our Collective Future in Aotearoa New Zealand
}

\begin{abstract}
This practice-research based article explores the relationship between mana motuhake and white patriarchal sovereignty in Aotearoa New Zealand, focusing on Ngāti Tūwharetoa as a case study. It seeks to find the relevance of Aboriginal academic Aileen Moreton-Robinson's white possessive doctrine to the Aotearoa New Zealand context. In particular, it highlights the racist nature of the law and planning systems and their inadequacies to provide for hapu and iwi. It provides a key theoretical analysis regarding the nature of white patriarchal sovereignty in Aotearoa and the need of the state to appear virtuous, to continue the legacy that started with the Treaty of Waitangi to maintain this whenua as a white possessive. Lastly, the piece questions the position of Britishness within Aotearoa New Zealand and asks key philosophical questions for all about the need to find common understandings or māramatanga about our collective future as a society.
\end{abstract}




\title{
Introduction
}

\author{
Tihei mauriora! \\ Tihei uriuri \\ Tihei nakonako \\ Ka tù \\ Ka tau haha te papa e takoto nei \\ Ka tū ka tū haha \\ Te rangi e tu nei \\ Ka tau, ka tau \\ Te matuku mai i rarotonga \\ Ko ia i rukuhia \\ Manawa pou roto \\ Ko ia i rukuhia \\ Manawa pou waho \\ Whakatina kia tina \\ Te more i Hawaiki \\ E pupū ana hoki \\ E wawau ana hoki \\ Tārewa tū ki te rangi \\ Aue kia eke \\ Eke Tangaroa \\ Eke Panuku \\ Whano whano \\ Haramai te tōki . \\ Haumi e, hui e, taiki e
}

'E kore e piri te uku te rino, ka whitingia e te rā ka ngahoro'1

Te Whiti o Rongomai

\section{$1.1 \quad$ Background}

In 2006, I graduated from the University of Waikato. Looking back, I was very young, fresh and idealistic. In my first hui, on my first day in the 'real world'2 at the Ministry of Fisheries, I asked a naïve question aloud about a proposed government policy: how does this provide for tino rangatiratanga ${ }^{3}$ and mana motuhake? The response was a deafening awkwardness, as if I had just opened Pandora's box. This question is never asked when dealing with Māori ${ }^{4}$ and environmental issues, particularly around 'natural resources'. Over the years, as I have developed as an environmental policy analyst and planner 
and then into a 'reluctant hapū ${ }^{5}$-based researcher', I have concluded that this makes no provision for either concept, particularly regarding 'natural resources'. As such, it begs the question: how does that affect my own hapū and iwi?

In 2016, one of my iwi6—Ngāti Tūwharetoa-is expected to receive a treaty settlement with the Crown over historical grievances that relate to the first encroachment of Pākehā ${ }^{7}$ on our rohe. ${ }^{8}$ This milestone is significant as the iwi will then be able to focus on rebuilding the iwi estate for future generations: or can they? The following is a practice-research discussion and exploration of issues around mana ${ }^{9}$ motuhake in Aotearoa New Zealand, with a focus on Tūwharetoa. It plans to disrupt and nullify the conventional government-led conversation about Te Tiriti o Waitangi (Te Tiriti) being the foundational document of Aotearoa New Zealand, that Te Tiriti validates Crown power, and that 'principles of the treaty' are the way which indigenous rights are provided to Māori. ${ }^{10}$ Of particular importance to this paper is the Indigenous Australian academic Aileen MoretonRobinson's white possessive doctrine. Key to embracing Tūwharetoa in a post-settlement environment is recognising our position as one of the many iwi that did not sign Te Tiriti, This act of non-signing is a major aspect of our identity as hapu of Tūwharetoa and a way for us as a nation to move past the issues of British colonisation in this country. Therefore, many questions require answers. At a professional level: how is Moreton-Robertson's white possessive doctrine relevant to planning? At an iwi level: how does the author justify vocal dissent in hapu and iwi-based research in an Indigenous context? At a national level: what would be the place of Te Tiriti, the Declaration of the Rights of Indigenous Peoples (DRIP) and the treaty principles if mana motuhake ${ }^{11}$ was recognised and implemented? How is Moreton-Robinson's white possessive doctrine relevant to Aotearoa New Zealand? Why should Te Tiriti not be considered the founding document of Aotearoa New Zealand? 
It is widely held by Tüwharetoa and a number of other iwi that they did not sign Te Tiriti making it impossible for the state to gain sovereignty. Additionally, this article will explain an that what is claimed by the state as sovereignty that allows it to govern the indigenous population according to the work of Aileen Moreton-Robibsion, Hemopereki Simon, and Mason Durie can be considered racist. These two key concepts will be outlined in full during the course of this article in an attempt to answer the question: How can the sovereignty of the nationstate in Aotearoa New Zealand be considered racist and nonexistent? ${ }^{12}$

\subsection{Who is Ngāti Tūwharetoa?}

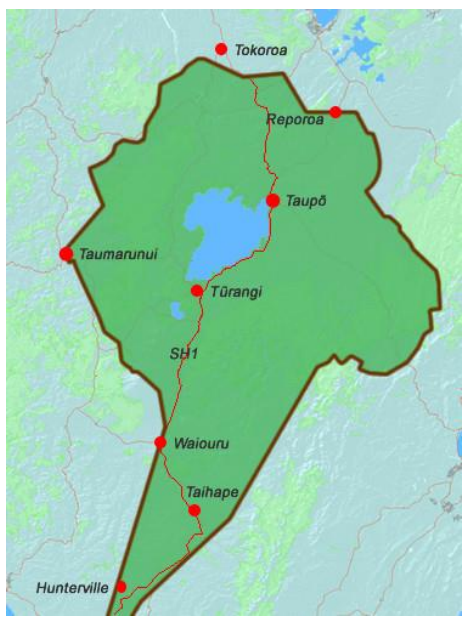

Figure 1: A general rohe map of Ngāti Tüwharetoa (source: Te Puni Kōkiri (TPK)) $)^{13}$

Tūwharetoa are an iwi that trace their whakapapa back to the Te Arawa waka. We claim ahi kaa and mana whenua rights to our rohe through the deeds of Ngatoro-i-rangi. When near death due to the cold upon ngā kāhui maunga, Ngatoro-i-rangi called 
upon his sisters to send fire. They did so, creating geothermal activity in Aotearoa New Zealand. This is highlighted in the oral history from the mōteatea 'Ka Eka Ki Wairaka'14 (https://www.youtube.com/watch?v $=\mathrm{zCb} 57 \mathrm{yZ5C3c}$ ).

The Ngāti Tūwharetoa rohe is in the Central North Island, around the Taupō Moana. There are several hapū of Ngāti Tūwharetoa, which are grouped into two names. This piece will focus on Te Hikuwai. These groups are north of Motutaiko; in particular, the hapū of Ngāti Rauhoto, Ngāti Te Urunga, Ngāti Tūtetawhā, Ngāti Hineure, Ngāti Hinerau, Ngāti Tūtemōhuta and Te Kapa o Te Rangiita ki Oruanui ('Ngā Hapū'). According to Statistics New Zealand, 35,877 people are affiliated with Ngāti Tūwharetoa; 59.1 per cent live in urban areas. ${ }^{15}$

\section{The Literature}

\subsection{Indigenous Rights}

Currently, the way in which Indigenous participation and involvement in government decision-making processes are provided for and monitored in Aotearoa New Zealand is via the 'Principles of the Treaty of Waitangi'. These were formulated by the fourth Labour government (1984-1990) in response to the 1987 landmark case of New Zealand Māori Council v. AttorneyGeneral.16 This was a culmination of the increasing politicisation of Indigenous issues in New Zealand from the late 1960 s onwards. Indeed, the past 40 years have witnessed a significant upsurge in Indigenous struggles and protests on a global scale; this has led to the increased political visibility of Indigenous groups. This culminated in the signing of the DRIP, 17 which has focused attention on the plight of Indigenous people in different countries. Since the 1990s, successive New Zealand governments have legislated settlement packages that provide some redress to iwi, hapu and urban Māori communities for their historical grievances against the Crown under the Treaty of Waitangi. In this context, the efforts of iwi 18 have been directed towards the revival of culture and language, 
the settlement of historical grievances and economic development. Government focus has largely been on recognising 'Māori rights' under the Treaty of Waita ngi. However, many iwi, including Ngāti Tūwharetoa, have not signed Te Tiriti o Waitangi, the Treaty of Waitangi or He Whakaputanga. 19

In terms of protecting Māori values and 'rights' and natural resources in government policy, this is encapsulated in the articles of Te Tiriti o Waitangi-particularly in Article 2. This article states: 'Ko te Kuini o Ingarani ka wakarite ka wakaae ki nga Rangitira ki nga hapu-ki nga tangata katoa o Nu Tirani te tino rangatiratanga o o ratou wenua o ratou kainga me o ratou taonga katoa' $[\mathrm{sic}]^{20}$ The English version clarifies the wants and desires of the British to control and possess natural resources. Article 2 states that 'full exclusive and undisturbed possession of their lands and estates, forests, fisheries and other properties ... so long as it is they wish to retain [them]. ${ }^{21}$ Regarding the premise of state sovereignty, we are aware of what took place. Ritchie states:

[e]verything that could have happened to destroy Māori culture has happened; dispossession of land; disruption of stable living; destruction of authority systems; invasive schools, language loss, disease, demoralisation; population decimation; trenchant assimilation policies; religious imperialism; subject to prejudice and monoculturalism; the setting of faction against faction; cultural takeovers; abdication of Treaty promises; capture of resources. All these are chapters of colonial and neo-colonial impact. ${ }^{22}$

Today, the 'Principles of the Treaty of Waitangi' inform the obligations of the Crown with respect to Māori involvement in the management of natural resources. This is important, as New Zealand's uptake of DRIP was on the condition that the rights provided by DRIP were consistent with the Principles of the Treaty of Waitangi: 'The importance of treaties is not only 
underscored by Indigenous peoples themselves, who see in it evidence of their nation-to-nation relationship with the states in which they now live. It is also confirmed in the constitutional law of countries such as Canada and New Zealand'. ${ }^{23}$ It is a given that in Aotearoa New Zealand the framework of Indigenous rights provides a narrative (largely made by government design) that says 'Māori signed the Treaty of Waitangi'. This agenda by policy makers groups all iwi and hapu into one entity: Māori. This is alarming on an iwi and hapū level, as John Rangihau notes:

My being Maori is absolutely dependent on my history as a Tūhoe person ... there is no such thing as Māoritanga because Māoritanga is an all-inclusive term which embraces all Māori. And there are so many different aspects about every tribal person. Each tribe has its own history [their own identity and their own politics]. ${ }^{24}$

This issue is of further concern due to the over-reliance on consultation under environmental laws like the Resource Management Act (RMA). Studies of Māori access to resources have focused not on mana motuhake but on the treaty notion of rangatiratanga. According to Matunga, the treaty anticipated two parallel planning mandates for natural resource management: a Māori planning mandate and Pākehā planning mandate: 'However,] ... the failure of successive colonial governments to honour these treaty rights has meant that Māori planning ... for the past 140 years occupied a space outside the Pākehā framework, through deliberate colonial exclusion. This notion is considered the fulfilment of rangatiratanga, as promised by the treaty'. 25

As this requirement to provide for the 'Principles of the Treaty' is so entrenched in resource management (particularly in relation to Indigenous rights), the focus of the central 
government has been to increase and enhance Māori participation in this area.

More recently, co-management for and/or with Indigenous groups has taken hold. In planning practice, reliance on consultation has reduced Tangata Whenua to a status akin to that of a 'special interest group'. This has been met by Māori demands to increase their level of influence in decision-making further. ${ }^{26}$ These demands are essential: most environmental planners and policy makers are [generally] non-Māori and as such, lack a basic understanding of Māori cultural values in resource management. ${ }^{27}$ Awatere et al. note that mātauranga ${ }^{28}$ is poorly understood by the planning profession, and when incorporated into planning (in particular documents) it is usually highly 'Europeanised' or co-opted into existing systems. This co-opting generally operates as an afterthought. ${ }^{29}$ Further, mainstream policy makers rely on those institutions and ideas with which they are most familiar, removing the political and cultural content of the mātauranga provided. This further marginalises Māori: in a New Zealand context, Māori systems are seen as honourable but without scientific rationale. An important consideration is that there is 'a major over-reliance on hui ${ }^{30}$ to get a "Māori or iwi ${ }^{31}$ perspective"' This has led to issues of 'hui fatigue'. ${ }^{32}$ This situation is concerning, as the over-reliance on consultation under environmental laws (like the RMA 1991), along with capability and capacity issues, creates an elite within hapu and iwi. ${ }^{33}$ Those who belong to the elite are ahi $\mathrm{kaa}^{34}$ living in or near the iwi rohe ${ }^{35}$ who may benefit financially from participation. In effect, this creates a privileged class.

Consultation is not expressly provided for in legislation by the RMA. This is significant, as this Act informs resource management and land use. However, Hagen considers it good practice for decision makers to engage in consultation so they understand the extent to which the assessment of environmental effects has been undertaken. ${ }^{36}$ Further, 'iwi consultation (in particular) is vital to enable decision makers to 
understand the cultural effects of an activity, particularly as regards the matters falling within sections $6(\mathrm{e}), 7(\mathrm{a})$ and 8 of the Resource Management Act'. 37 As Kawharu notes, legislation is the way in which kaitiakitanga is provided for in environmental planning. ${ }^{38}$ This is less than desirable as it takes an Indigenous concept and redefines it in a foreign way, co-opting the concept and transforming it in a way that suits the coloniser. ${ }^{39}$ As Moreton-Robinson (2005) reminds us:

The British imperial project was predicated on taking possession of other peoples' lands in a number of ways... The right to take possession was embedded into British and international common law and rationalised through a discourse of civilisation that supported war, physical occupation and the will and the desire to posess. Underpinning property rights, possession entails values, beliefs, norms and social conventions, as well as legal protection, as it operates idealogically, discursively and materially. 40

In 1493, after Columbus stumbled across the continent now referred to as 'the Americas', the Pope, Alexander VI, issued a papal bull designed to prevent infighting between the Portuguese and Spanish monarchs over territory in the New World. The new bull, Inter Caetera, became a major document in international law surrounding claims of right by European powers to empire. Essentially, Toesing describes the doctrine as 'a 500 year old trade agreement between competing Christian countries'. ${ }^{41}$ This bull is considered the founding document of the doctrine of discovery (also referred to as 'the doctrine') It is comprised of ten parts or elements. The elements most important to Tūwharetoa will be highlighted here:

1. First discovery. The first European country to discover lands unknown to other Europeans gained property and sovereign rights over the lands. However, first 
discovery alone was often considered to create only an incomplete title for newly found lands.

2. Native title. After first discovery, Indigenous nations and peoples were considered by European legal system to have lost the full property rights and ownership of their lands. They only retained occupancy and use rights. Nevertheless, these rights could ostensibly last forever if Indigenous people never consented to sell: they could only sell to the government that held the power of pre-emption over their lands. Thus, native title is considered a limited form of ownership.

3. Indigenous nations' limited sovereign and commercial rights. After first discovery, Indigenous nations and peoples were also considered to have lost some of their inherent sovereign powers and their rights to free trade and diplomatic relations internationally. Thereafter, they were only supposed to deal with the European government that had first discovered them.

4. Terra nullius. This term means a land or earth that was empty, null or void. The phrase vacuum domicilium was also sometimes used to describe this element. It literally means an empty or vacant home or domicile. Under this element, lands that were not possessed or occupied by any person or nation, or were occupied by nonEuropeans but were not being used in a way that European legal systems understood and/or approved, were considered empty and wasted, and available to be claimed. Europeans were very liberal in applying this definition to the lands of Indigenous peoples. Europeans often considered lands that were actually owned, occupied and being actively used by Indigenous peoples as vacant and available for discovery claims if they were not being properly used according to European laws and cultures.

5. Conquest. This element appears to have two different definitions. It definitely referred to the rights Europeans 
claimed to acquire by winning military victories over Indigenous peoples. We will see that definition reflected in Spanish, English and American ideas of 'just wars' that allegedly justified the invasion, conquest and acquisition of Indigenous lands in certain circumstances. ${ }^{42}$

These elements of the doctrine were created and defined by a United States of America (US) Supreme Court case, Johnson v McIntosh in 1823. Here, conquest was deemed a 'term of art'. This meant that in the first instance, conquest was undertaken by military conquest as the Europeans discovering a country claimed political, real property and commercial rights over the native people who would be integrated into the conquering power's nation. However, the US Supreme Court held that in the case of the US, the accepted European principle of conquest had to be modified, as Indian Nations could not be left in complete ownership of the US. This meant that even without war or military engagement they were already considered a conquered people. This allowed the European power to usurp their rights legally. This case is important to Aotearoa New Zealand as it is the precedential basis for Māori affairs in R v. Symonds. ${ }^{43}$ Therefore, the doctrine was interwoven into the colonial thinking of the British upon their arrival and the subsequent construction of their colony in Aotearoa New Zealand. This is a part of what Moana Jackson calls 'the culture of colonisation'. ${ }^{4}$ The original idea of British colonisation was the notion of 'plante'. 45 This is a key concept in the philosophy underpinning the justifications and development of British colonisation. The concept called for Britain to 'plante' Britishness on the lands, minds and people of the desired possession; in this case, Aotearoa New Zealand. 


\subsection{White Possessive Theory and Aotearoa New Zealand 46}

This literature identifies 'whiteness' as the invisible norm against which other races are judged in the construction of identity, representation, decision making, subjectivity, nationalism, knowledge production and the law. ${ }^{47}$ MoretonRobinson contends that:

Race has shaped the development of Australian law just as it has influenced the morphology of law in other former colonies, such as the United States, where a body of critical race theory has emerged to reveal the racialisation of law... I reveal how the possessive logic of patriarchal white sovereignty works ideologically, that is it operates at the level of beliefs, and discursively at the level of epistemology, to naturalise the nation as a white possession. Australia was acquired in the name of the King of England. As such patriarchal white sovereignty is a regime of power that derives from the illegal act of possession and is most acutely manifested in the form of the Crown and the judiciary. The Crown holds exclusive possession of its territory, which is the very foundation of the nation-state. ${ }^{48}$

Regarding Canada, Val Napoleon (writing on Indigenous law) comments:

Imagine that the world that you know, that the law starts to disintegrate to the point where you can no longer rely on it. Where your rights and your protects won't be upheld. Maybe the ownership of your property will become questioned, maybe it will be denied. What will happen to civilians? What will happen to you sense of citizenry? Your sense of safety? Your ability to act on your sense of right and 
wrong? So this is what has happened to Indigenous law. It causes a profound sense of disorientation, a displacement, a loss of mooring of who we are as a people, and a family, as individuals. So our communities experience the consequences of this. We see manifestations of violence, we see the undermining of Indigenous peoples as selfdetermining, as self-governing, as people who are responsible for ourselves. For our law, our governance, our economies, our social fabric... Indigenous law hasn't gone anywhere it exists within our communities, it is damaged, it continues to exist in some formal ways as well as in informal ways. Informally it determines our normative commitments our sense of the right and the wrong relationship, our obligations with each other and other non-human life forms. Formally, it occurs in the institutions that we are building and create a meaningful relationship with 'Canada'. 49

From an Aotearoa New Zealand perspective, Simon states that 'We must acknowledge that Aotearoa New Zealand was built on the idea of racism and white privilege, like other English settler colonies'.50 Mason Durie notes that the introduction of The English Acts 1854 was one of the first pieces of legislation passed by the settler government. He states '[i]n a single statute the Act made all English laws binding in New Zealand with a proviso, introduced in 1858 that the English laws applied only so far as they were applicable to the circumstances of New Zealand'. ${ }^{51}$ This privileges European-derived law over the traditional law of Māori, tikanga. Legislation like this was enacted to privilege the settler society over and above the needs or desires of Māori.52 In doing so, it ignored tikanga as the already-established legal tradition in Aotearoa New Zealand. Moreton-Robinson argues that: 
Governments were responsible for facilitating and appropriating Indigenous lands and through the use of law enabled the death of Indigenous peoples who impeded progress. Governments dehumanised Indigenous peoples in order to legitimise their actions and then sought to make us fully human by exercising benevolence and virtue in its many forms. ${ }^{53}$

Moreton-Robinson further contends that:

Reveal[ing] how the possessive logic of patriarchal white sovereignty works ideologically, that is it operates at the level of beliefs, and discursively at the level of epistemology, to naturalise the nation as a white possession. Australia was acquired in the name of the King of England. As such patriarchal white sovereignty is a regime of power that derives from the illegal act of possession and is most acutely manifested in the form of the Crown and the judiciary. The Crown holds exclusive possession of its territory, which is the very foundation of the nationstate. 54

This statement also holds true in the case of Tüwharetoa and Aotearoa New Zealand. A contributing factor to the presence of whiteness in Aotearoa New Zealand is differences in approach and philosophy. Aroha Mead notes this in her Difference in Approaches Theory. ${ }^{55}$ Interestingly, this comparative theory can be used to compare the differences in philosophies and practices between Pākehā and Māori, to see whether the approach is grounded in tikanga and is a kaupapa Māori or whiteness approach. The elements of difference are listed below:

1. One solution for many diverse problems-all or nothing syndrome 
Antithesis on developing policy on an iwi by iwi [or even hapū by hapū] basis

2. Wanting to see results in one's own lifetime-shortterm goal setting Intergenerational responsibility

3. Having to experience something first hand to understand it and/or want to protect it Mauri, ihi, wehi, mana are intangibles that Mãori protect without 'experiencing them firsthand'

4. Innovating and modifying nature Protect and caring for what is already there

5. Compartmentalising, listing and sub-dividing Reaffirming the holistic, interdependency of social, cultural, environmental and economic factors

6. Commodifying nature and knowledge Too bizzare to even comment on

7. Focusing on the rights of individuals Collective rights are the legitimising norms and standards for Indigenous people. ${ }^{56}$

\subsection{Mana Motuhake}

Jones asserts that 'mana is the central concept that underlies Māori leadership and accountability'. ${ }^{57}$ Mana is described by Marsden as 'spiritual power and authority as opposed to the purely psychic and natural force-ihi', 58 and by Mutu as 'power, authority, ownership, status, influence, dignity, respect derived from the gods. 59 There are many types of mana, but of most importance in the current research are the concepts of mana whenua and mana motuhake. 60 If mana in this case is deemed authority and power, then the term 'motuhake' is understood as 'separated, special, distinct, independent, unattached. '61 'Ka wera hoki te ahi, e mana ana anō'62 - this whakatauki63 defines the related concept of ahi kā, ${ }^{64}$ which must be involved in any claim of mana whenua. ${ }^{65}$ Mana whenua is described as: 
[Customary] Authority over land and therefore the right to occupy those lands. This in brief is the way Māori determine 'ownership' to the land. Land (or whenua) is a tūpuna, an ancestor, through whom this mana has been acquired through whakapapa by the present day descendents (or uri). ${ }^{66}$

Cox affirms that mana whenua is derived from 'a special relationship [with the land] ... developed over generations of occupation and control'.67

Carwyn Jones asserts Māori had constitutional traditions that were/are pan-tribal or whakapapa-based.68 These traditions are informed by the traditional tikanga values of: whanaungatanga, mana, utu, manaakitanga, tapu and noa. Of these, mana is a key concept that requires investigation, particularly regarding its interaction with sovereignty discourse and the concept of mana motuhake. When dealing with Māori there is an on-going dialogue in which hapu and iwi maintain that mana motuhake was never ceded or given away. Two groups are involved in this debate: those who signed He Whakaputanga, creating a Māori state and government in 1835 and/or Te Tiriti o Waitangi, and those who did not sign anything, thus maintaining mana motuhake. In relation to the former, a summary report (entitled 'Ngāpuhi Speaks') of evidence presented to the Waitangi Tribunal conclusively demonstrates that:

1. Ngāpuhi did not cede their sovereignty.

2. The Crown had recognised He Whakaputanga as a proclamation by the rangatira of their sovereignty over this country.

3. The treaty entered into by the rangatira and the Crown-Te Tiriti o Waitangi-followed on from $\mathrm{He}$ Whakaputanga, establishing the role of the British Crown with respect to Pākehā.

4. The treaty delegated to Queen Victoria's governor the authority to exercise control over hitherto lawless 
Pākehā people in areas of hapu land allocated to the Queen.

5. The Crown's English language document, referred to as the Treaty of Waitangi, was neither seen nor agreed to by Ngāpuhi and instead reflects the hidden wishes of British imperial power. ${ }^{69}$

These assertions were recently upheld by the Waitangi Tribunal. 70

In an environmental planning context, the key concepts of mana whenua are examined here, as they relate to planning and interrelatedness:

1. Tangata Whenua ${ }^{71}$ can be defined as people of the land-autochthonous, Indigenous or first nation[s] people.

2. Mana whenua applies to Tangata Whenua with mana over their lands-they speak for their turrangawaewae [and what should happen in it]. 72

3. Kaitiaki ${ }^{73}$ can be mana whenua, within their tribal boundary. ${ }^{74}$

Cox observes that 'This dualism of power and authority incorporates the notion that not only is a rangatira the "lawful" agent and leader, he (or she) is spiritually empowered to direct the affairs of the people'. ${ }^{75}$ Reflecting upon that statement, Durie comments that such power was exercised at a hapu $\bar{u}^{76}$ level, 77 flowing in a bottom-up rather than top-down fashion, and that a centralised super-ordinate was 'antithetical'.78

Discussions of mana in a modern context must include mana motuhake. ${ }^{79}$ Due to translation errors between Te Tiriti and the Treaty of Waitangi, two very different documents were created. 80 What is significant here is the difference between the terms 'kawanatanga' and 'sovereignty': 'Article 1 of Te Tiriti renders "sovereignty" as kawanatanga (governorship), while in Article 2 the idea of the undisturbed possession of Māori lands and 
taonga (property/treasure) is translated as tino rangatiratanga (absolute chiefly authority)'. ${ }^{81}$ Durie argues that other concepts such as rangatiratanga 82 or Arikitanga 83 could have been implemented in the pursuit of sovereignty. ${ }^{84}$

In political theory, sovereignty denotes absolute legal and political authority over a defined territory, and the right of the state to make and enforce laws, collect taxes and other such official activities. ${ }^{85}$ However, Croxton states that the concept is challenging:

no final and absolute authority exists elsewhere is the only possible approach to explaining the role of a treaty in establishing the principle of sovereignty. No piece of paper can ever establish exclusive authority in a given territory; only administrative practice can do that. The most the paper can do is convince people that states ought to have exclusive territorial authority. 86

By this definition, 'sovereignty is not a fact. Authority and power are facts ... [Sovereignty] is an assumption about authority'. ${ }^{87}$ This renders the idea of Indigenous sovereignty unrealistic and absurd: a goal and concept that does not exist. 88 Therefore, sovereignty is provided for legally through international law, but not politically. 89

The mana motuhake, or third mana, is 'an ancestral vehicle'. ${ }^{90}$ The following ngeri and statements demonstrate how values and cultural awareness of this mana motuhake, along with how Māori exercised that kaitiaki responsibility and ingrained in into our culture. It cries:

E ko te Tui! E ko te Tui!

E ko te hono ki te kōtahitanga,

Ko te Kìngi Māori e tū nei!

E tū $i$ runga te mana motuhake e tū nei!

Ana! Whiti! Whiti! 
Whiti ki te tika!

Whiti ki te ora!

Whiti ki te ranghimārie!

I titia iho

Au! Au! ha! Aue hā ! 91

This is further demonstrated in Ngāti Pōrou and Ngāti Tūwharetoa. When asked to become the Māori King, 92 Te Kani a Takirau replied:

Ehara tāku maunga a Hikurangi i te haere,

He maunga tū tonu;

Ko tōku kīngitanga nō te pō mai ra anō

Nō ōku tīpuna, mātua!93

This is echoed by Mananui Te Heuheu's statements to Jerningham Wakefield:

I am King here, as my fathers before me, and as King George and his fathers have been over your country ... You white people are numerous and strong; you can crush us if you choose, and take possession of that which we will not yield; but here is my right arm, and should thousands of you come, you must make me a slave or kill me before I will give up my authority or my land ... Do not bring many white people into the interior, who may encroach on our possessions till we become their servants [sic]. ${ }^{94}$

This is a very interesting statement for Tūwharetoa, as it openly acknowledges that mana motuhake is interconnected with land and thus natural resources.

According to Te Kenehi Teira, Kaihautu Māori for Heritage New Zealand on the carving style of Motu Heta, he carved this series of whare after the invasion of the Waikato. These whare are a 
commentary on unceded mana motuhake. This is demonstrated in the unusual width of the whakairo and the subject matter carved on the maihi being: Te Ara o Tawhaki. ${ }^{95}$ Thus whakairo demonstrate linkages between the hapu and/or iwi, their connection to their tūpuna, and different types of mana, in particular mana motuhake, and the whenua.

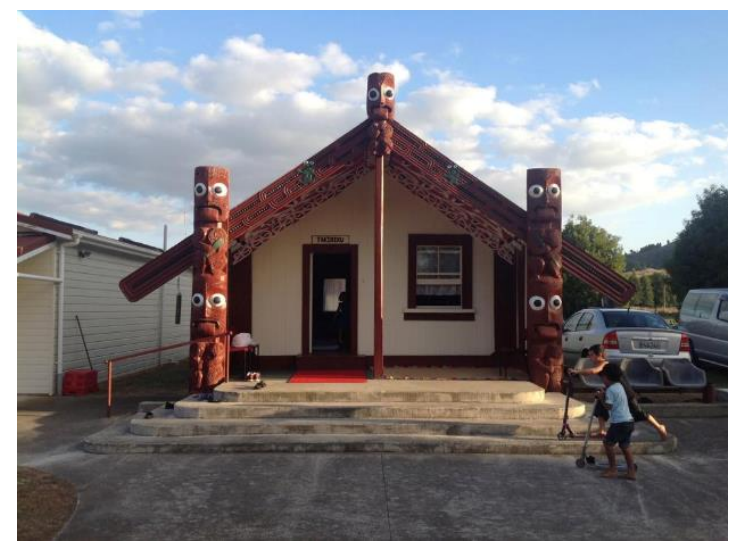

Figure 2: Takihiku, Owairaka Marae

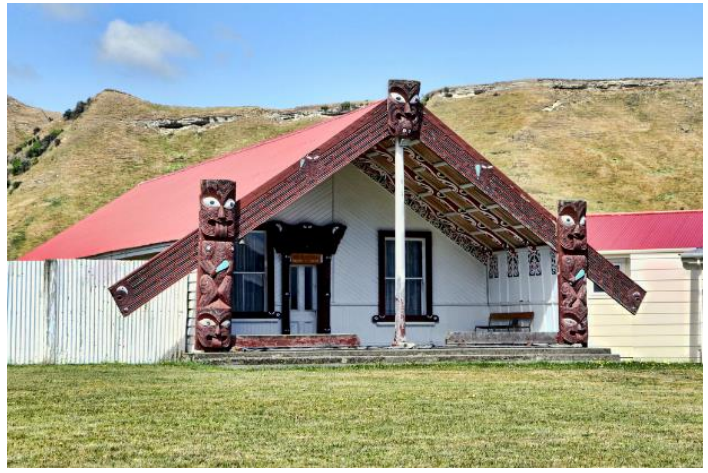

Figure 3: Whitikaupeka, Mowhango Marae 


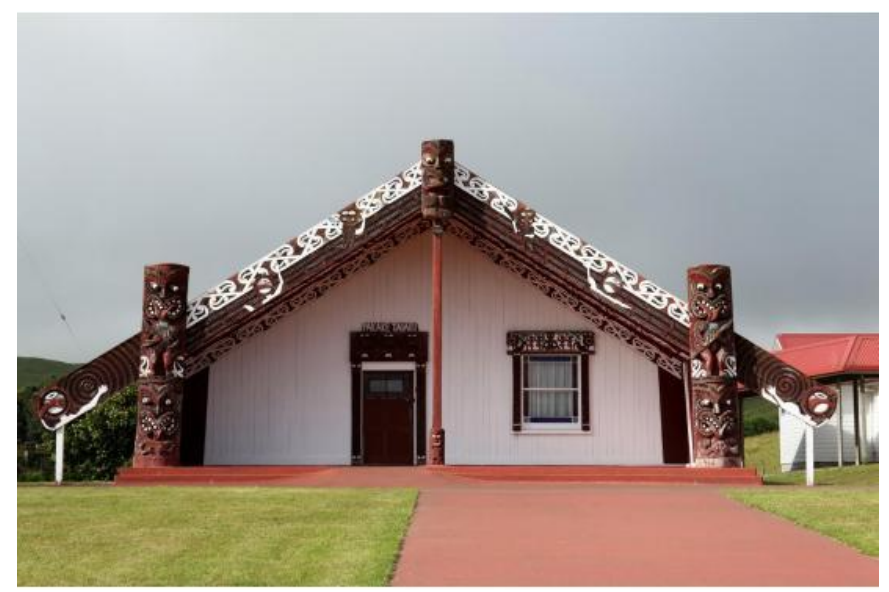

Figure 4: Pakaketaiari, Mokai Marae

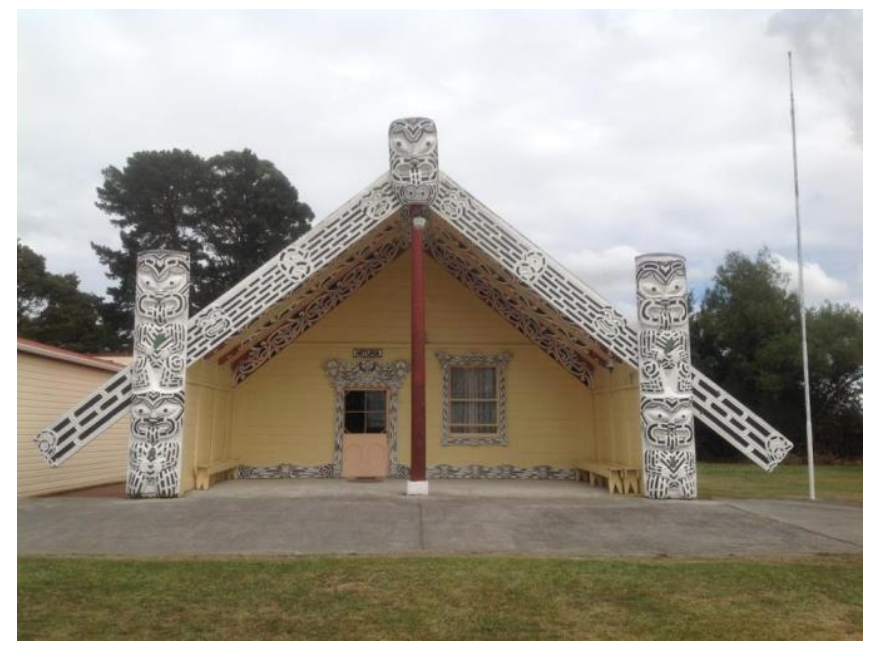

Figure 5: Hoturoa, Aotearoa Marae 


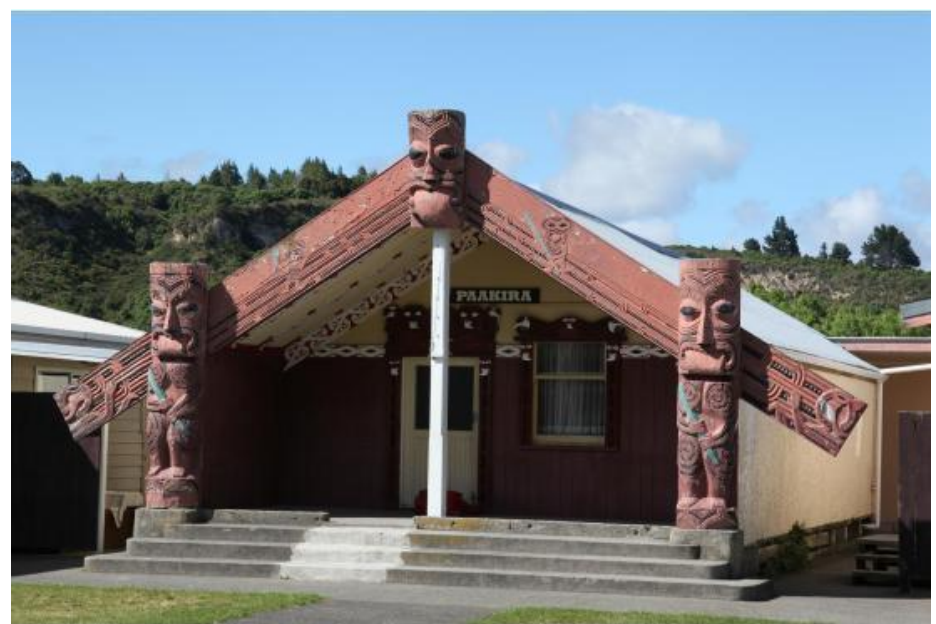

Figure 6: Paakira, Waitahanui Marae

Figures 2 to 6 Are examples of the Mana Motuhake whakairo style of Motu Heta.

According to Moreton-Robinson, the international literature since the 1990s about Indigenous sovereignty and rights has proliferated. This literature raises fundamental questions about the democratic state. It also challenges, on philosophical grounds, key concepts such as democracy and sovereignty. Accordingly:

sovereignty is born of war enabled by a mythology of the divine right of kings. Sovereign absolutism was marked by gender and race in the seventeenth century, though race was considered a linguistic marker. Patriarchal white sovereign absolutism, though internally fractured, waged war to appropriate land and resources. Thus the foundations of modern sovereignty has a gendered and racial ontology - that is, sovereignty's divine being as a regime of power is constituted by and through gender and race. The transition from 
sovereign absolutism to its modern form was produced through a counter-discourse of rights through the challenge to the King's power by his knights. 96

Moreton-Robinson declares that when Foucault argues metaphorically that modern sovereignty is represented as a headless King whose body is still intact, he is discussing the manifestation of sovereign power within the modern state:

In this way, sovereign power is a state's internal selfrealisation of its truth and virtue, whereby will and possession operate discursively. Virtue functioned as useable property within the legal doctrine of discovery, which provided the rationale for sovereign wills to take possession of Indigenous peoples' lands. 97

She contends that, in terms of the virtuous state:

[w] henever the state proclaims its ownership, the state's assertion that it owns the land becomes part of normative behaviour, rules of interaction and social engagement embodied by its citizens. It is most acutely manifested in the form of the state and the judiciary. Thus possession and virtue form part of the ontological structure of patriarchal white sovereignty that is reinforced by its socio-discursive functioning within society enabled by the body of the state. 98

Moreton-Robinson furthers this argument:

As part of state-formation and regulation, patriarchal white sovereignty is mobilised through a possessive logic that operates. This is a form of rationalisation rather than a set of positions that produce a more or 
less inevitable answer, which is underpinned by an excessive desire to invest in reproducing and reaffirming the state's ownership, control and domination. The possessive logic of patriarchal white sovereignty is compelled to deny and refuse what it cannot own - the sovereignty [or in this case the mana] of the Indigenous other. ${ }^{99}$

This illustrates how claims for mana motuhake challenge conceptualisations of state sovereignty. This literature's limitations lie in its reliance on 'rights' as the cipher through which to analyse Indigenous sovereignty and mana motuhake. Foucault argues that rights is both an instrument of, and vehicle for, the exercising of the multiplicity of dominations.... For this reason, rights should not be understood as the establishment of legitimacy but rather the method by which subjugation is carried out. 100 Academic disciplines using an argument about Te Tiriti and the principles of the treaty subjugate iwi who did not conform to the wishes of the Crown and signed; in practice, it privileges the rights of others. Using rhetoric about a 'founding document' ignores Tūwharetoa and our experiences of the colonial process. This argument only moves to uphold the state's status quo and patriarchal white sovereignty, as it legitimises the existence of that state. It also reveals how the state has worked to modify and justify its existence while maintaining its claims to white patriarchal sovereignty and a possessive stake in Aotearoa New Zealand.

\subsection{Race, Mana Motuhake and 'Indigenous Rights'}

Most importantly, the British introduced the notion of race to Aotearoa New Zealand. This is where:

[a]t the time self-superiority was integral to the British worldview at every level ... These period beliefs conflated physical characteristics, based mostly on 
skin colour, with cultural and historical characteristics, including attributed morality, and then judged on a scale of primitive to sophisticated, with the Europeans and the British-inevitably-at the top. ${ }^{101}$

In summarising the work of Foucault, Moreton-Robinson says that:

[r]ace became a means of regulating and defending society from itself. That is, war continues in modernity in different forms, while sovereignty shifts from a concern with society defending itself from external attacks to focus on its internal enemies. Race became the means through which the state's exercise of power is extended from one of 'to let live or die', to one of 'to let live and to make live' 102

This ontological disturbance/fracture is one reason that explains why the state deploys virtue when working to maintain racial and gendered domination in the guise of good government. Virtue functions through reason within sets of meanings about patriarchal white ownership of the nation within the law. This is part of commonsense knowledge, decision making and socially produced conventions by which societies live and govern behaviour. The possessive logic of patriarchal white sovereignty has defined the attributes of personhood and property through the law. ${ }^{103}$ As Harris argues, the theft of Indigenous lands has been ratified by bestowing and 'acknowledging the property rights of whites in [Indigenous lands]. Only white possession and occupation of land was validated and therefore privileged as a basis for property rights'104. The possessive logic of patriarchal white sovereignty was deployed in defining who was-and who was not-white, conferring privilege by identifying what legal entitlements accrued to those who were categorised as white. 105 
Irene Watson and Taiaiake Alfred advocate abandoning the concept of Indigenous sovereignty as it is configured in debates about Indigenous rights ${ }^{106}$. Ivison et al. argue that a new political theory should include acknowledgement of Indigenous difference as an essential condition of the legitimacy of the institutions and practices within which rights and resources are to be distributed. 107 Second, the universalism of liberalism and the particularism of Indigenous rights should not be perceived as mutually exclusive, but rather as reference points to begin a new form of negotiation. Behrendt challenges the logic of formal equality by providing a clear and coherent articulation of Indigenous rights claims and the need for social justice. 108 These important and valuable examples from the literature offer detailed analyses of the racism embedded in the historical, political and legal treatment of Indigenous sovereignty within the framework of sovereignty, rights and law. They illustrate how Indigenous sovereignty claims have challenged conceptualisations of state sovereignty and, in a few instances, how this has worked to modify state rights through domestic and international law. The limitation of this literature lies in its reliance on 'rights' as the cipher through which to analyse Indigenous sovereignty. It does not reorient our conceptualisation of power outside a law, right or sovereignty paradigm to think about Indigenous sovereignty and power in different ways. White possession manifests as a mode of rationality in a variety of academic disciplines. 109

In particular, we could examine how these mentioned academic disciplines have operated as normalising modes of rationality that facilitate procedures of Indigenous subjugation and mask non-Indigenous investments in relations of patriarchal white sovereignty. This is to ask to what extent does white possession circulate as a regime of truth that simultaneously constitutes white subjectivity and circumscribes the political possibilities of Indigenous sovereignty. White possession as a concept. According to the judicial-philosophical tradition, possession is the foundation of property; it requires physical occupation and 
the will and desire to possess. Possession of lands is imagined to be held by the King, and in modernity by the nation-state (the Crown) that holds exclusive possession on behalf of its subjects. Therefore, possession is tied to rights and power. MoretonRobinson further argues that:

the possessive logic of patriarchal white sovereignty operates discursively, deploying virtue as a strategic device to oppose and subsequently endorse the Declaration. As an attribute of patriarchal white sovereignty, virtue functions as a useable property to dispossess Indigenous peoples from the ground of moral value. 110

These states disavow the collective rights of Indigenous peoples by positioning themselves as virtuous states that govern in the interests of other legal rights in land. The discursive twist in the use of 'other legal rights', to implicitly appeal to diversity, is an attempt to deflect attention from the protection of the white government's sovereign rights' claim. In effect, they are proclaiming that land already owned and occupied under state sovereignty will not be diminished or changed by Indigenous proprietary rights. With missionary zeal, these states have already determined what is best for 'their' Indigenous peoples by defining what Indigenous rights are acceptable; in this way, they stake a possessive claim to us as a paternal right.

\section{Discussion}

\subsection{Discussion}

In terms of whiteness and mana motuhake, due to a government-led agenda and a search by hapu and iwi for acceptance of their existence, we have become very accommodating. Non-signatory hapu and iwi have and continue to suffer due to the racist attitudes of the British that deemed themselves to have paternal rights over uncivilised barbarian 
peoples. The notion of 'treaty rights' for non-signatory hapu and iwi is irrelevant, as we have been consistently pressured into this situation by war and destitution. This has continued with the Crown ignoring us or interfering due to a belief that it holds white patriarchal sovereignty as a few hapu rangatira signed a document that apparently represented all of Te Ao Māori, according to the white possessive logic and paternalism of the British. This has led to a consistent redefinition of the meaning and place of Te Tiriti in Aotearoa New Zealand by the judiciary. As non-signatory hapu and iwi, we have forgotten or at least pushed the inconvenient stories of our histories to the side due to their inconvenience to the current government-led kaupapa. By doing this, we have accepted whiteness. We accept the judiciary and their creation of the 'Principles of the Treaty', we accept that the Crown has the right to dominate us, we accept governance systems that are highly corporatised. Many other examples could illustrate this point. This raises the question: have we, as hapu and iwi, become too accommodating?

However, the point being made here is that in doing this, we fail. We fail to recognise that white patriarchal sovereignty is not a guarantee. It is actually a falsehood; as stated by Croxton, it is only an assumption about power. ${ }^{111}$ We do not recognise the importance of mana that is not a 'right' but an inherited responsibility passed down from our tūpuna. If we do not uphold our mana the first thing we fail is our tūpuna, followed by our uri whakatupu. If we ignore our responsibilities and conduct kaitiakitanga within a legislative framework or adhere to the will of the Crown and conform by making inadequate treaty settlements, ${ }^{112}$ we fail as hapu and iwi to have integrity as Indigenous peoples. One form of mana is interconnected to other forms of mana: if we do not maintain one form of mana, we as a people end up with no mana at all. This is important for non-signatory hapu and iwi, as mana motuhake is a key part of our identity and constitutional traditions. We have become complacent and accepting of 'rights' as the structure through which we reaffirm our existence as Indigenous people. Have we 
as an iwi and the Ariki/Arikitanga become Mananui's proverbial 'slave?'

The consistent redefinition of Te Tiriti by the judiciary questions their role in the suppression and subjugation of iwi and hapu by implementing the law. Although it may seem progressive, The New Zealand Māori Council v Attorney-General case, if seen from a non-signatory hapu and iwi perspective, can only be described as an attempt by a white possessive society to subjugate these groups further. This is made worse by the lack of recognition (for the common law doctrine around treaties and contracts) of contra perferentem. This is acknowledged as being applicable to Te Tiriti but has not been implemented by the government due to its potential ramifications for the white possessive state. Ultimately, the judiciary and its decisions ${ }^{113}$ are consistent and desperate attempts by the white possessive state in Aotearoa New Zealand to deny hapu and iwi their history and lived experiences as non-signatory hapu and iwi. In doing this they seek to void tikanga and its key principles surrounding mana being: mana whenua and mana motuhake. Additionally, this continues to ensure that hapu and iwi like Tūwharetoa remain stuck in a vortex, where they must seek legitimacy for their existence in the face of white possessive logic from the entity that legitimised their colonisation. This has occurred in Tüwharetoa in many ways, as demonstrated above. However, it can be traced back to the iwi's resistance, or forced participation resulting from the Crown's 'scorched earth' policy with Tūhoe, of defending mana motuhake and mana whenua from white invasion at Te Pōrere.

As demonstrated above, the British placed much emphasis on natural resources, in particular land, in the treaty. Combining this with a declaration of doctrine for Te Wai Pounamu and a perceived right of paternalism over Te Ao Māori led to the establishment of white patriarchal sovereignty in Aotearoa New Zealand. To gain recognition of their existence in relation to the government's and settler society's white possessive logic, nonsignatory hapū and iwi have had to resort to arguing points 
around Te Tiriti instead of engaging in the true intention of our tūpuna. In Tūwharetoa, this first began at the leadership level in Tureiti Te Heuheu's time. White possessiveness logic was legitimised to our whenua by seeking 'rights.' In this case, 'rights' are provided by the headless monarch: the state.

At this juncture, it must be noted that Māori did not have a 'monarch' in the European sense. Indigenous sovereignty is not conceivable in this way. This is because, to have sovereignty, you must have a monarch ordained by God.114 Māori sovereignty, like the sovereignty provided to Native Americans, can only be provided by the state. This is a side effect of Johnson v. McIntosh.115 Therefore, it is vital to clarify the point of focusing so much attention in this paper on mana. Mana is a key concept. As Jones suggests, it encapsulates the constitutional traditions of hapu and iwi. Mana, as opposed to sovereignty, is factual. It is grounded in the physical environment and is a key cultural component. It is provided to us by our tūpuna, and as suggested, by Te Kani a Takirau. However, unlike the Christian-European God, Ngā Ātua are culturally proven to be part of or represented in the environment. Faith is not required to know that Ngā Âtua exist. Therefore, to claim 'Māori sovereignty' is a form of state legitimisation and the claim by Pākehā for white possessive sovereignty. However, as Coxton mentions, sovereignty cannot be granted by a piece of paper. ${ }^{116}$ In Tūwharetoa and a number of non-signatory iwi, it is questionable as to whether the state's sovereignty actually exists; if it does, can it only be justified through illegal and morally questionable acts.

Moreton-Robinson highlights how settler societies, by ratifying the DRIP, seek to be virtuous as a way of claiming the moral ground, providing rights to Indigenous groups in light of their less then flattering colonial legacies. ${ }^{117}$ They do so as Indigenous groups like hapu and iwi have a case where they could legitimately question the white possessive sovereignty of the state in Aotearoa New Zealand. However, to further Moreton-Robinson's argument, in the case of Aotearoa New 
Zealand the idea of the state's virtuousness extends back to the signing of Te Tiriti and the declarations of paternalism. Through these actions, representatives of the British Crown ensured it was in the best interests of all Māori if all hapu and iwi, including those that did not sign, became British subjects. This was the beginning of the subjugation of all non-signatory hapu and iwi. It was also the start of the state evolving to legitimise itself and its claim to white patriarchal sovereignty and Aotearoa New Zealand as a white possession. This included introducing common law and the judiciary that continues to uphold what in modern times may be the hidden whiteness of the law and its perpetuation of racism. What this may be seen as is the continued predatory pathology of the possessive logic of the white possessive settler state and society against hapu and iwi. This is continued in the DRIP, where non-signatory hapu and iwi are again forced into this paternalism by the clause in DRIP that states in Aotearoa New Zealand what is to be provided should be consistent with the Principles of the Treaty.

This form of paternalism and assimilation is evident in RMA planning. This is where kaitiakitanga is supposed to be provided for. This can only be seen as a further attempt by the white possessive state to appear virtuous by providing for Indigenous rights. However, as the literature suggests the interpretation of this would at best be lacking from a hapu and iwi perspective, as the planning profession lacks the ability to accommodate matauranga in a genuine manner. This can be seen as a side effect of planning practice's colonial roots. This approach defined and civilised the 'natural landscape' in a way familiar to European sensibilities, logic and possessiveness. ${ }^{118}$

A key question will be asked as a result, which is ultimately the key question: what would mana motuhake look like in modern times if it ever became a reality? It would be unreasonable for the author to write this article and not provide some suggestions on how this concept could be achieved in a contemporary situation. We as Tūwharetoa are othered, and we acknowledge this through our lived experience every time we acknowledge 
Taupō as 'white' and in doing so feel displaced in our own rohe. However, this should not be surprising in a society that has been 'whitewashed' and not taught the history and experiences that Māori have suffered under colonisation. What needs to take place is a very long and in depth discussion about the place of hapu and iwi in the future of this country. Central to this discussion is not more of the usual talk around the treaty and providing for treaty rights, but instead addressing the multiple realities that exist. It is obvious to me that change in the environmental planning framework needs to occur through my research work and my professional experience in the environmental sector. ${ }^{119}$ At a minimum this could mean (as previously suggested by Matunga) a dual planning system. We must recognise that the idea of removing Pākehā is absurd and unachievable. We must recognise that our tūpuna extended manaakitanga to these people and we as hapu and iwi must recognise that regardless of what has transpired as a result.

A suggestion from the hapū of Tūwharetoa, if mana motuhake was recognised, would be in terms of planning: planning applications should meet two types of 'law' and thus two types of legal systems. In a gradual staged development, planning that allowed the hapu to develop capacity-environmental use would be totally administered by the iwi and the functions of entities like the Waikato Regional Council and the Department of Conservation would in time be the domain of the hapū; unencumbered by notions of 'race' and 'paternalism.' Potentially, this could mean a treaty between the New Zealand government, the British Crown and the hapu of Tūwharetoa. This may establish a federated state solution similar to that of France and New Caledonia. The author suggests that these suggestions are far from what hapu and iwi want. This would be supported by the recent actions of another non-signatory iwi, Tūhoe. They recently positioned themselves to take over the administration of key social development entities like schools (http://www.nzherald.co.nz/nz/news/article.cfm?c_id=1\&obje $\underline{\text { ctid }=11546918}$ ). I question the perception that this is only 
possible in Tūhoe. If we as Tūwharetoa already own the land under the district's schools, why would it be so absurd for us to administer them as well? However, Toby Curtis from Te Arawa notes that 'they support Tuhoe's ambitious bid to take over their social services but say Te Arawa does not need to do the same. Te Arawa is already leading the country when it comes to economic and social development'. ${ }^{120}$ Therefore, the situation raises the question for Tüwharetoa of what we should employ to achieve a form of mana motuhake in the present. If we are, is it working?

The biggest questions for Aotearoa New Zealand concern the role of the environment in our collective future. If we are discussing the future and the nation's engagement with Māori, this significant factor needs to be addressed. In particular, the place of planning and planning systems in our future requires focus. Building on the assertions of Matunga in the event that planning in a mana motuhake framework was to eventuate, a clear definition must be established. Mana motuhake can be described by the interpreting the literature above as an autonomous or independent power that is factual and held by either hapu or iwi, similar to sovereignty but grounded in the whakapapa connection of mana whenua to their ancestor Papatūānuku and their legal system of tikanga. It is an obligation and responsibility of every generation to protect, safeguard and ensure it continues intact. Understanding this is vital to the planning profession in Aotearoa New Zealand; providing for Māori is framed as 'Tangata Whenua', which is a mismatch. What they are doing is aligned more with the term 'Mana Whenua'. However, I would guess that the reason 'Tangata Whenua' has been used is due to its accessibility. It is very difficult to explain completely the concept of mana to nonMāori, particularly to planners.121 If mana motuhake were implemented, in line with Matunga's ideas of a dual planning system, a key potential feature of this planning system is that it would be grounded in tikanga and Māori philosophy. It would also most likely be based around a form of consensus. ${ }^{122}$ 
However, Matunga's ideas have a dual purpose. While he could be seen as explaining a dual planning system, he inadvertently provides the example of racism, particularly under the law in planning. That is, there is a racist notion that exists of the supreme law' in which European law is enforced. This must be observed by all, thus cementing white patriarchal sovereignty on the landscape, bodies and minds of people. This is racist, as the underground system of law that exists, like in Matunga's example, tikanga is not enforced upon all. It could be argued that in administrative practice, terms like tikanga and mana motuhake are only practiced today within the confines of the marae complex. However, in planning under the RMA, a neoliberal-based system, rights are provided to the property owner or developer while in practice hapu and iwi are reduced to having the status of a special interest group. This highlights the problem in modern Aotearoa New Zealand: when you combine the privilege of the RMA with a lack of understanding around mātauranga, it is clear that the nature of planning in Aotearoa New Zealand is institutionally racist or at a minimum biased against Māori. After all, planning exists to serve the colonial machine and the RMA and planning can be considered a form of violence, as Gunder and Mouat suggest. ${ }^{123}$

This is not surprising. One of the key problems with both treaty settlements and planning concerns the lack of understanding that Pākehā have about Te Ao Māori. There is no education in place for everyone to gain at least a minimum understanding of tikanga, Te Reo or civics. This is how the Prime Minister, John Key could consider the settlement of Aotearoa New Zealand as 'peaceful'.124 Thus, it allows the state to assert power and provide minimal 'rights' and settlement to hapu and iwi. This is problematic and an abuse of power, as the state created this situation initially through colonisation. It is a way for the state to maintain its control and its white patriarchal sovereignty resulting in maintaining Aotearoa New Zealand as a white possessive. The Treaty Negotiations Minister Chris Finlayson 
demonstrates this most aptly in his response to the Waitangi Tribunal report, Te Paparahi o Te Raki:

The Tribunal doesn't reach any conclusion regarding the sovereignty the Crown exercises in New Zealand. Nor does it address the other events considered part of the Crown's acquisition of sovereignty, or how the treaty relationship should operate today. ${ }^{125}$

He says the government will consider the report, just like all others from the Tribunal:

The Crown is focused on the future and on developing and maintaining the Crown-Maori relationship as a Treaty partner. That's why we are so focused on completing Treaty settlements in a just and durable manner. ${ }^{126}$

Minister Finlayson's focus on settlement is important as it removes the moral argument from Māori and positions the government as virtuous, suggesting that we are moving forward as a country and being progressive. Therefore, it could be considered that a treaty settlement is merely a device for placation. It ignores the illegal formation of the state over Tūwharetoa and makes us, as an iwi, continue to operate as if we were captive and othered in our own rohe. Settlement is a concern, as it allows the Crown to apologise while continuing unhindered or unchanged in the way things are done. 


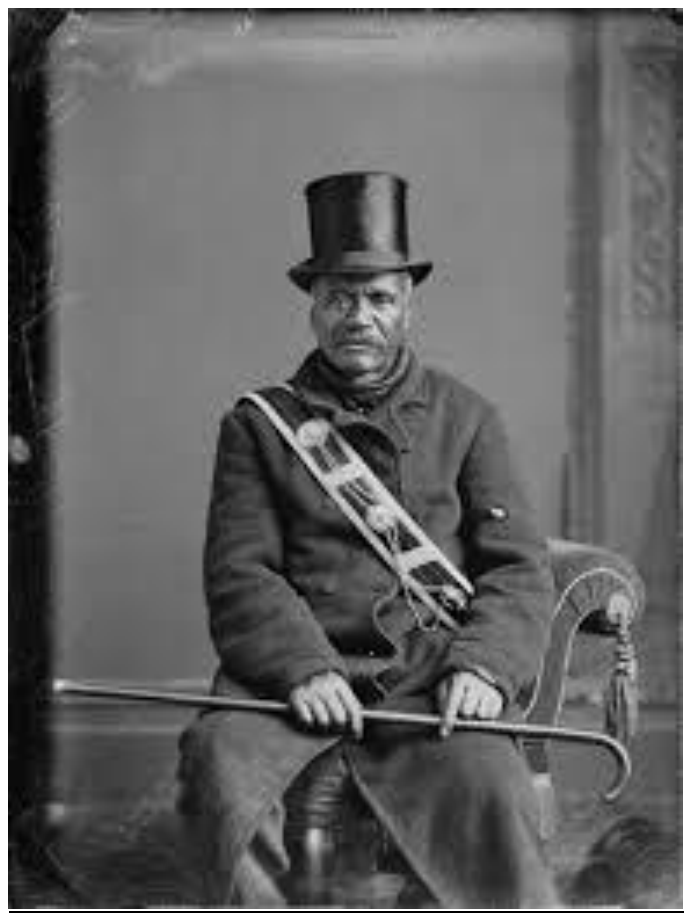

Figure 7: Horonuku Te Heuheu Tukino IV (Source: Alexander Turnbull Library Ref: 1/4-022227-G)

\subsection{Post Settlement Future of Tūwharetoa}

However, if viewed in light of the material written above, white possessiveness and whiteness is ever-present in Tüwharetoa. It manifests itself in the positions of the elite, in particular the Ariki/Arikitanga. This is because history shows us that this process began with the state's determination to take possessive control of ngā kāhui maunga for tourism. We must remember that at the time, Horonuku was no passive bystander. He actively supported the state in their proposals. ${ }^{127}$ This was to salvage what mana he could from an impossible situation. In doing so, he supported their objectives in full.128 This lies behind the wants and desires of the white possessive logic of 
the state. In doing this, he questioned a fundamental concept of our identity as a collective, our mana and where exactly did it lay? By doing this, he contributed to the collapse of our traditional governance system. ${ }^{129}$ However, and to be fair, each successive generation of leaders who acquired the role of Ariki has had to engage in what can only be described as a delicate balancing act.

In terms of the current Ariki, Tā Dr Tumu Te Heuheu, recent settlement documents suggest that the apparent role of the Ariki is as a 'safekeeper' or 'kaitiaki' of the tikanga and traditions of the iwi. ${ }^{130}$ This definition was reached by a series of hui, described as a hikoi where a series of hui were held with the hapu of Tüwharetoa. The result was that this currently proposed treaty settlement provides further funding and/or validity to the Arikitanga. It brings into question where the mana of the position lays which arguably a good case can be made that the Crown controls and validates the position and has done so since the late 1800 s. This should have been enacted regardless of funding being sought from the iwi. However, the venture was sold as the Ariki listening to the people, during the meeting I attended at Waipahihi Marae. However, if analysed from a tikanga perspective this type of hikoi should have occurred on day one of the current Arikitanga, as was/is the case with our iwi's tikanga. This recent hikoi has been the only one since the beginning of this Arikitanga, which began in 1997. These actions speak to the values operating in Tüwharetoa, particularly at the elite level; that is, within our leadership is the ever-present control of whiteness that has created a norm that we as whānau, hapu or iwi do not question. That is the place and role of the Ariki and most of all its true place and purpose in modern Tūwharetoa, not the thin veneer of spin that has been created to appease the masses. Questioning the functional statement of the Ariki in our post-settlement future is not enough. We as whānau, hapu and an iwi must begin to question ourselves critically and provide answers to the following questions. What is the true role of the Ariki in a post- 
settlement Tūwharetoa? How much input and/or control should the Ariki/Arikitanga have over the running of the iwi? How and why should the Arikitanga be held accountable to the people it serves? Is there space for the continued existence of an Arikitanga in our collective post-settlement future? Fundamentally, this should be done with a critical research agenda; however, that is unlikely in Tūwharetoa.

It is a condemnation of the iwi and Arikitanga that people with skills and much to offer our collective development are routinely silenced or ignored to pursue questionable aims. However, the indictment is that a commentary in a journal must be written for dissenting voices or voices grounded in tikanga to be heard and hopefully for change to occur. The point about writing research like this is clear. This conversation should have taken place before we engaged in a government-led settlement process clearly designed to produce division rather than find common understanding: māramatanga. In approaching a postsettlement era as an iwi we need to be mindful that māramatanga is the common factor that consistently needs to be established. Otherwise, we will end up in a cycle of fighting each other after the settlement deal has been established, as has happened with other iwi. ${ }^{131}$ We also need to increase accountability across the board within the iwi. Without accountability we will continue to make mistakes like the example of losing $\$ 20+$ million of treaty settlement money. 132 It is clear to the author that we, as Tüwharetoa, have over time, become complacent. We do not ask these types of questions, at least openly. Many will question my purpose for doing so. If this is the case, know that I am engaging in walking and breathing our tikanga. I am not seeking fame or notoriety although, by publishing, I am undoubtedly aware that the latter will follow. I am doing this because our uri whakatupu deserve better than that which we have today. I am also aware that some of the material discussed in this paper may seem politically unfeasible at present. My reply if questioned will be this. I do not write for today but for the benefit of those yet to be born. They will 
achieve my work and attain what is deemed impossible now. My work is intended for 30 years from now when the climate will have changed. Look at what we as Māori have achieved in the past 30 years, despite the treaty and government policy. Hope for us as a people can only be found through an ability to dream. This is what colonisation sought to remove: that is what I seek to instil.

I am using the pūmanwa provided to me by our tūpuna to engage 'the possible'. I assume a position as a tōhunga. ${ }^{133} \mathrm{My}$ approach is simple and ultimately grounded in the tikanga of those hapū that nurtured me. In pursuit of māramatanga, the approach should be analysed in accordance with Mead's theory. ${ }^{134}$ In this way, the approach will determine how it meets the tikanga standards, as it seeks to develop policy and approaches that deal with things on a hapū by hapū basis, and dealing with the multitude of problems we have in an open and transparent manner. In line with Mead's theory, it seeks to promote intergenerational responsibility, the intangible aspects of our culture like ihi, wehi, tapu and mana. These also happen to be some of the key concepts in our constitutional traditions. It looks to care for and protect what is already there environmentally; it reaffirms the holistic and interdependent nature of our people. It commodifies neither nature nor mātauranga and most of all it seeks to legitimise and normalise our collective rights and standards. It meets all the philosophical standards established by Mead.135 For if I as an individual or we as a collective do not question and provide for uri whakatupu situations (such as the loss of millions of dollars with no accountability for the decision making that has occurred:

(http://www.waateanews.com/waateanews/x_story_id/MTI0O $\mathrm{TA}=/$ National/Tuwharetoa fills coffers/). A key question for this discussion is who ultimately benefits from this nonaccountability? Why do they benefit? Should this be the way of governance? Who facilitated this decision-making? Despite this discussion occurring on an international stage in academia, the 
author is aware of the appropriate membership for participation in this iwi discussion and that is for us who are whakapapa to Tūwharetoa.

It seems that what is being offered in the settlement deal is that we are once again moving as an iwi to rectify Horonuku's dealings and restore mana to the Te Heuheu name. Instead of adhering to political expediency, do we really need to accept a settlement that only delivers what is politically acceptable by today's standards? If approximately 2 per cent, a limitation of our maunga co-management and the Department of Conservation estate is what is being offered, this begs the question: is that really in the best interests of our uri whakatupu? Could not more be done? What are we sacrificing as an iwi and as individual hapu for the reputation of one whānau? If this is the case, what would our uri whakatupu say? That is the marker of our tikanga moving forward. Unfortunately, the current settlement proposal seems to be wrapped in Western philosophy. If analysed from Mead's Difference in Approach Theory perspective, this settlement is being pushed as government policy. It has been born as one solution for diverse problems-an all or nothing approach. It ignores the need for an intergenerational approach. It is being ploughed through as short-term goal setting, where results are required within a person's lifetime or (in this case) by the end of an imposed government policy cycle. It is very focused on the uplifting of the mana and of a single whānau or person, instead of the collective benefit.136 It is clear that this concept of settlement does not provide for the future of Tūwharetoa, as funds are lacking to provide fully for the iwi's needs. Two key questions should be asked: should we as an iwi accept a settlement that is not of an acceptable standard, one that will not provide for the complete needs of our future development? Should Members of Parliament ratify settlement deals that are fundamentally flawed, particularly if they are aimed at the notions of redress and the achievement of social justice? 


\subsection{Aotearoa New Zealand's Constitutional Future}

Fundamentally the biggest concern is the constitutional issues raised in this article. This is because the state in Aotearoa New Zealand administers this country based on an unwritten constitution. It could be argued that no written constitution was ever undertaken; in this way, the state can maintain and reproduce white patriarchal sovereignty and hold Aotearoa New Zealand as a white possessive. However, there are bigger issues here: what is the place of the environment in our common collective future? This is important given the environmental degradation being generated by farming intensification and its overall impact on the environment. 137 This is also strongly interconnected to another question, given the relationship with and intangible whakapapa link to the environment: what is the role and value we place on hapu and iwi in our collective future? I believe that this article has clearly demonstrated the need to question the white patriarchal sovereignty of the state in Aotearoa New Zealand. This is best described as shaky, illegal and an unfounded claim based on racism, possesion and possibly bio-power. It is also deeply integrated into the British culture of colonisation that includes the doctrine of discovery. The element of terra nullius was declared in this country for the Te Wai Pounamu (South Island) after the signing of Te Tiriti. For the other hapu and iwi of the Te Ika a Maui (North Island), that did not sign, the British representatives assumed control under the notion of paternalism. This leaves iwi like Tūwharetoa in a political, moral and legal vacuum, as we were not conquered.138 Ultimately, the continued support of the Catholic, Anglican, and other churches needs to be called into question. This doctrine provided the legal and moral justification for colonisation. In the year 2016 should something like this even exist? Should these Churches like the white possessive states pay compensation? We never consented to the overtaking of our mana by the white possessive logic and white patriarchal sovereignty of the state. The problem with settlement is that the representative of the 
state standing and delivering a negotiated apology and the LNG $^{139}$ is supposed to accept this. This approach is steeped in western and most of all Christian ethos of forgiveness. It also highlights the racism as a 'term of art' as suggested in Johnson $\mathrm{v}$ McIntosh around the European monarch conquering Indigenous people without a 'just Christian war.' It is as if the apology is proverbial: 'yes we did all that; now, let's all join hands and sing kumbya'. Clearly, a white possessive logic is at play here: civilisation arrived in the form of Britishness and additionally, Christ... are you not grateful? The fundamental problem here is that the state hopes to look virtuous without highlighting there is no recognition of mana motuhake and the traditional constitutional values of hapu and iwi. The state wishes to maintain itself as 'sovereign' and continue its acts undisturbed and not dealing with the real issue which is about equitable sharing of power with hapu and iwi or recognition of mana.

This challenges the conventional government-led conversation in Aotearoa New Zealand about Te Tiriti being the country's foundational document. It should only be seen as the document used to validate a claim to white patriarchal sovereignty by the state. This is seen in the way in which the judiciary has changed the meaning of Te Tiriti over time, through the cases brought before it. Over the past 40 years, academia has also been guilty of replicating this myth and by association, ensuring the continuation of white possessive sovereignty and the possessive logic of the state. The conversation about Te Tiriti being the foundational document of Aotearoa New Zealand ranks equally as bad as the other myth that Aotearoa New Zealand has the best race relations in the world. ${ }^{140}$ This is ultimately highlighted by Professor Paul Moon's statement following the Te Paparahi o Te Raki report by the Waitangi Tribunal (http:/ / www.waateanews.com/Waatea+News.html?story_id=O $\underline{D M} 3 \mathrm{Mw}==8 \mathrm{v}=64) .141$ Despite this, a conversation about the future of Te Tiriti needs to occur, particularly with nonsignatory iwi. Paternalism and suppression has been a key 
feature of government in Aotearoa New Zealand and this should not be allowed to continue. Until this is achieved and racism removed as the basis of law in this country, Te Tiriti and/or DRIP as they are written (without the interpretation of the treaty principles) need to remain in place as minimal safeguards against the state's possessiveness. Recent examples of this is seen in current arguments around who has ownership rights to water. We as Aotearoa New Zealand need to address these important constitutional issues, in particular the place and value of Māori, hapū and iwi in our collective future. This must be done before a republic is established.

Finally, white patriarchal sovereignty, possesiveness and society must not be defended. Neither should Indigenous peoples be seen as internal enemies of the state and civilisation, as suggested by Foucault, which is created by the existence of racism. We are an integral part of the collective future of Aotearoa New Zealand. To this end, the famous question posed by Justice Eddie Durie is the wrong question: when will the settler settle? The relevant question here is this: when will the settler learn to settle? For, if we agree there is a collective future for all who live in Aotearoa New Zealand then Pākehā New Zealand must learn to integrate into a collective where their privilege and assumptions are nullified and tested. They must become more accepting of ways that are not imported or tethered to Britishness, ways that serve us equitably as a collective. The example of this is the recent actions of New Plymouth Mayor and proclaimed 'recovering racist,' Andrew Judd.

(https://www.youtube.com/watch?v=Kh1nyb7UKRM) ${ }^{142}$ (http://www.radionz.co.nz/national/programmes/checkpoint /audio/201804958/new-plymouth-councillors-leaveparihaka-hikoi). ${ }^{143}$

\section{Conclusion}

This article is a theoretical and philosophical discussion piece. The author recognises that further research on this topic is 
required; this article creates openings for that to take place. To facilitate these openings, a practice-research approach was used. According to the author:

To facilitate ... [these openings] a practice research [approach] was used. It must be noted that with practice research there is no conclusion. This is due to the fact that the function of practice is always ongoing. Future research will contribute, further, or move the research conversation in different directions. However, practice... is fluid and continues. With this in mind this article cannot provide a conclusion but advice on possible directions research could pursue. ${ }^{144}$

First, the author recognises the need to engage those hapu involved in the case studies of this research. This should incorporate a qualitative approach to further understand the need to increase Māori participation in planning and development, particularly around key concepts in the planning future of Aotearoa New Zealand, such as mana motuhake.

Ultimately, the title of this article (if translated into English) proposes this meaning: 'the elephant in the room'. This is because the major objective is to unmask the hidden, to speak up to power, and to facilitate what is, for many (in particular non-Māori) a difficult and often misunderstood area of our nationhood as Aotearoa New Zealand. However, in this context the overall question is for any research is: how do we move forward into an uncertain future where the sovereignty of the state is at best shaky and very questionable? We must recognise that Te Tiriti is not the so-called founding document of this country. It is used in this way to establish and legitimise the nation-state in Aotearoa New Zealand over and above the inherited mana of hapu and iwi. We must move past the colonial model provided to us by Britain. For us as a nation to mature and overcome the significant obstacle of the colonial process, 
we must fully embrace and accept Te Ao Māori. ${ }^{145}$ While this paper is merely a discussion piece, I acknowledge that further qualitative research is required to follow up on the issues raised. This will occur with the completion of my doctoral thesis over next year and possibly throughout my career.

A key feature of the developing conversation is the focus our country should take to provide a platform for a common ground. Manuka Henare offers something about Te Ao Māori that could be considered useful. He notes:

Māori religion is not found in a set of sacred books or dogma, the culture is the religion. History points to Māori people and their religion being constantly open to evaluation and questioning in order to seek that which is tika, the right way. ${ }^{146}$

The future approach to Indigenous issues in Aotearoa New Zealand needs to be based in the concepts of tika, as mentioned, and pono. It relates to discovering the common ground between hapu and iwi and the rest of the nation. Every person will need to approach this with an open mind and a willingness to engage in an informed manner. This is a mediated approach and not one based on absolute power. This approach needs to take place in an open and transparent manner, based on the idea that we are providing for social betterment and the collective good, with restitution and social justice in mind. This may include rethinking the way in which we undertake healthcare, through to how people are punished. This is necessary in a whitewashed society like Aotearoa New Zealand, as it provides Pākehā with an opportunity to learn and grow with us as hapu and iwi. Pākehā need to understand that:

Colonisation imposed a terrible separatism upon us, it separated us from our lands, it separated us from our rights, it separated us from our power and we are simply trying to reclaim those. ${ }^{147}$ 
This journey forward allows Pākehā to learn new ways of doing things, based on Indigenous principles. This, in particular the economic and environmental development, is interconnected with our existence as beings with whakapapa, the health of the environment, and the equitable sharing of power based on mana whenua and mana motuhake. Effectively, three things must change in our collective future: the legal system, the planning system and society overall.

It is fitting to conclude this article with a philosophy to provide us with direction as we move forward as whānau, hapu and iwi. In the words of renowned Jamaican philosopher and singer Robert Nesta 'Bob' Marley, in his Redemption Song (https://www.youtube.com/watch?v=QrY9eHkXTa4):

\author{
Won't you help to sing \\ These songs of freedom? \\ 'Cause all I ever have, \\ Redemption songs, \\ Redemption songs.
}

Emancipate yourself from mental slavery,

None but ourselves can free our minds.

Have no fear for atomic energy,

'Cause none of them can stop the time.

How long shall they kill our prophets,

While we stand aside and look?

Some say it's just a part of it,

We've got to fulfill the book. ${ }^{148}$

In terms of our traditional philosophy as Māori, the two whakatauki $\overline{1}$ that filful the same sentiment of Marley are as follows:

Tama tū, tama ora, tama noho, tama mate 149 
Ka pū te ruha, ka hao te rangatahi ${ }^{150}$

This means that to grow as a people, we must be become active participants in our development. For, if we sit and become inactive, we will eventually perish as a people and as individuals. However, this means engagement in multiple ways from participating in growing your own reo through to becoming an active dreamer regarding our collective future direction and hopefully being vocal about it. Inevitably, we must engage rangatahi in this discussion, as they are the ones who will replace us. Providing for their dreams and aspirations is vital to attaining the ability to exercise mana motuhake outside the usual white possessive framework.

Kia tau ahau ki raro. Kua ea!

Note 1: This piece was written in loving memory of Lawrence Xavier Storey (Ngāti Maniapoto, Waikato-Tainui, Tūwharetoa) 1952-2014. Me hoki atu koe ki o tūpuna. Moe Mai Rā.

Note 2: An earlier version of this paper was presented at The New Zealand Political Studies Association Annual Conference 2015, Massey University, Palmerston North, November 2015. Note 3: The author acknowledges the contribution and kindness of Waikato-Tainui and the Kingitanga to the development of this work by granting the Te Arataura Postgraduate Scholarship to the author. This was gratefully received. 


\section{References}

3 News. 'Waitangi Tribunal: Northland Maori Didn't Cede Sovereignty', Mediaworks, 14 November 2014, available from http:/ / www.3news.co.nz/nznews/waitangi-tribunalnorthland-maori-didnt-cede-sovereignty-2014111413ixzz3uwY8Fg5I, accessed 28 December 2015.

Anderson, Robyn. Töngariro National Park: An Overview Report on the Relationship between Māori and the Crown in the Establishment of the Tongariro National Park. Wellington: The Crown Forestry Rental Trust, 2005.

Awatere, Shaun, Harmsworth, Garth, Rolleston, Shadrach and Craig Pauline. 'Kaitiakitanga O Ngā Ngāhere Pōhatu: Kaitiakitanga of Urban Settlements'. In Reclaiming Indigenous Planning, edited by Ryan Walker, Ted Jojola and David Natcher, Montreal: McGill-Queen's University Press, 2013.

Benton, Richard, Frame, Alex and Meredith, Paul eds. Te Mātāpunenga: A Compendium of References to the Concepts and Institutions of Māori Customary Law. Wellington: VUW Press, 2013.

Black, Taiarahia. 'He Mana Tō Te Waiata Tāwhito,' 181-196. In Matariki: A Monograph (Wellington: Te Mata o Te Tau/Massey University, 2011).

Bramwell, Chris. "Peaceful Settlement" View Challenged', Radio New Zealand, 2015, radio broadcast.

Behrendt, Larrisa. Achieving Social Justice: Indigenous Rights and Australia's Future. Annandale: Federation Press, 2003.

British Crown, Te Tiriti O Waitangi. Waitangi, 1840.

- The Treaty of Waitangi. Waitangi, 1840.

Cox, Lindsay. Kotahitanga: The Search for Māori Political Unity. Auckland: Oxford University Press, 1993.

Coxton, Derek. 'The Peace of Westphalia: Of 1648 and the Origins of Sovereignty'. The International History Review, (2010): 569591, doi: 10.1080/07075332.1999.9640869.

D'Hauteserre, Anne-Marie. 'Embracing Postcolonial Geographies: Contributions by Dame Evelyn Stokes to the Development of Postcolonial Geography in New Zealand'. New Zealand Geographer 61, no. 2 (2005): 102-109.

Durie, Edward Taihakurei. 'Ancestral Laws of Māori'. In Huia Histories of Maori: Ngā Tāhuhu Kōrero, edited by Danny Keenan, Wellington: Huia, 2012.

,When Will the Settlers Settle?' Otago Law Review 8, no. 4 (1994):449-466.

Durie, Mason. 'Race and Ethnicity in Public Policy: Does It Work?' In The Social Policy, Research \& Evaluation Conference 2004, Wellington, 2004.

Foucault, Micheal. Society Must Be Defended. London: Penguin, 2003.

Glanville, Luke. Sovereignty and the Responsibility to Protect: A New History [in English]. London: University of Chicago Press, 2014. 
Gunder, Michael and Clare Mouat. 'Symbolic Violence and Victimization in Planning Processes: A Reconnoitre of the New Zealand Resource Management Act'. Planning Theory 1, no. 2 (2002): 124-145.

Hagen, Kirsten. 'Māori Interests in Natural Resource Management: 2012 in Review,' Mãori Law Review 3 (March 2013), http://maorilawreview.co.nz/2013/03/maori-interests-innatural-resource-management-2012-in-review.

Harvey, Jennifer. Whiteness and Morality: Pursuing Racial Justice through Reparations and Sovereignty. New York: Macmillan, 2007.

Henare, Manuka. 'Te Tangata, Te Taonga, Te Hau: Māori Concepts of Property', paper presented at the Conference on Property and the Constitution, Wellington, 1998.

Henry, Ella and Hone Pene. 'Kaupapa Māori: Locating Indigenous Ontology, Epistemology and Methodology in the Academy'. Organization 8, no. 2 (2001): 234-242.

Hinsley, FH. 'The Concept of Sovereignty and the Relations between States'. In In Defense of Sovereignty, edited by WJ

Stankiewicz, New York: Oxford University Press, 1969, 275.

Ihaka, Kingi. 'Proverbial and Popular Sayings of the Māori: Nga Whakatauki me Ngā Pepeha Maori,' Te Ao Hou 18 (May 1957),

http://teaohou.natlib.govt.nz/journals/teaohou/issue/Mao1 8TeA/c20.html.

Ivison, Duncan, Paul Patton and Will Sanders (eds) Political Theory and the Rights of Indigenous Peoples. Cambridge: Cambridge University Press, 2000.

Jackson, Moana Facebook Video (n.d.), accessed 10 October 2015, https://www.facebook.com/sina.browndavis/videos/472543 05932/.

'The Culture of Colonisation', Te Pūtahi-a-Toi (Māori Studies) Massey University, 2011.

Johnson v. M'Intosh (1823) 21 US 543 (US Supreme Court).

Jones, Carwyn 'A Māori Constitutional Tradition'. Paper presented at

Unearthing New Zealand's Constitutional Tradition Conference,

Wellington, 2013.

Kawharu, Merata. 'Kaitiakitanga: A Māori Antropological Perspective of the Māori Socio-Environmental Ethic of Resource Management,' The Journal of The Polynesian Society 109, no.4 (2000): 349-370.

Kiingitanga. (n.d.) 'History', accessed 29 December 2015, http://www.kiingitanga.com/history/.

King, Michael. The Penguin History of New Zealand. Auckland, NZ: Penguin Books, 2003.

Te Puea: A Life. Auckland: Reed, 2008.

Marks, Greg. 'Indigenous Peoples and Sovereignty', Australian Human

Rights Commission Seminar Series. 10 November 2004.

Canberra, ACT: Australian Human Rights Commission. 
Marsden, Māori. 'God, Man, and the Universe'. In Te Ao Hurihuri: The World Moves, edited by Micheal King,Wellington: Hicks Smith, 1975, 145.

Māori Dictionary, 'motuhake', accessed 17 December 2015, http: / / maoridictionary.co.nz/search?idiom $=\&$ phrase $=\&$ prove

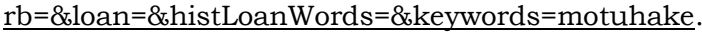

Marley, Robert 'Bob' Nesta (Bob Marley and The Wailers). Redemption Songs. [lyric] Uprising. Kingston, Jamaica: Island/Tuff Gong, 1980.

Matunga, Hirini. 'Decolonising Planning: The Treaty of Waitangi, the Environment and a Dual Planning Tradition. In Environmental Planning in New Zealand, edited by Ali Perkins and Harvey Memon. Palmerston North: Dunmore Press, 1993.

McKinley, Elizabeth. 'Brown Bodies, White Coats: Postcolonialism, Māori Women and Science'. Discourse: Studies in the Cultural Politics of Education 26, no. 4 (2005): 481-496.

Mead, Aroha. 'Ngā Tikanga, Ngā Taonga: Cultural and Intellectual Property: The Rights of Indigenous People'. In University of Auckland, edited by The International Research Institute for Māori and Indigenous Education. Auckland, 1994.

Mead, Hirini Moko. Tikanga Māori: Living by Maōi Values. Wellington: Huia, 2003.

Mead, Sidney M, Neil Grove and Maori Studies Victoria University of Wellington. Dept. of Maori. Nga Pepeha a Nga TuPuna. Wellington, NZ: Dept. of Maori Studies, Victoria University of Wellington, 1994.

Watkins, Tracy. 'NZ Does U-Turn on Rights Charter', stuff.co.nz, 20 April 2010, available from http:/ / www.stuff.co.nz/national/politics/3599153/NZ-doesU-turn-on-rights-charter, accessed 9 November 2015.

Mihaka, Kelly. 'Tūhoe Can Do Better Job: Curtis'. The Daily Post, 19 November 2015. http://www.nzherald.co.nz/rotorua-dailypost /news / news /article.cfm?c_id=1503437\&objectid=11547 $\underline{735 .}$

Mikaere, Ani. 'How Will the Future Generations Judge Us? Some Thoughts on the Relationship between Crown Law and Tikanga Māori'. Paper presented at the Mā te rango te waka ka rere: Exploring a Kaupapa Māori Organisational Framework Conference, Ōtaki, 2006.

'Te Tiriti and the Treaty: Seeking to Reconcile the Irreconcilable in the Name of Truth'. In He Rukuruku Whakaaro: Colonising Myths Māori Realities, 123-146. Wellington: Huia, 2011.

Mikaere, Ani and Jackson, Moana 'Kei Tua o Te Pae 2015: Researching Rangatiratanga, Innovating Mātauranga', NZCER, 2015, accessed 11 October 2015, https://www.youtube.com/watch?v=wr1mnW9a1Wg.

Miller, Robert. Discovering Indigenous Lands: The Doctrine of Discovery in the English Colonies [in English]. Oxford: Oxford University Press, 2010. 
Miller, Robert and Elizabeth Furse. Native America, Discovered and Conquered: Thomas Jefferson, Lewis \& Clark, and Manifest Destiny. Westport, CT: Praeger Publishers, 2006.

Ministry for the Environment and Ministry for Agriculture and Forestry. 'Wai Ora: Report of the Sustainable Water Programme Action Consultation Hui', edited by author. Wellington: Government Printer, 2005.

Ministry for the Environment and Statistics New Zealand. 'Environment Aotearoa New Zealand', edited by author. Wellington: Government Printer, 2015.

Moreton-Robinson, Aileen. 'The House That Jack Built: Britishness and White Possession'. Australian Critical Race and Whiteness Studies Association Journal 1, no. 1 (2005): 21-29.

'The Possessive Logic of Patriarchal White Sovereignty: The High Court and the Yorta Yorta Decision'. Borderland e-journal 3, no. 2 (2004). http://www.borderlands.net.au/vol3no2_2004/moreton_pos sessive.htm

'Towards a New Research Agenda?: Foucault, Whiteness and Indigenous Sovereignty'. [Paper in Special Issue: Beyond the Margins/Beyond Marginality.] Journal of Sociology 42, no. 4 (2006): 383-95, doi: 10.1177/1440783306069995.

Aileen. 'Virtuous Racila States: The Possessive Logic of Patriarchal White Sovereignty and the United Nations Declaration on the Rights of Indigenous Peoples'. Griffith Law Review 20, no. 3 (2011): 641.

Mulholland, Malcolm and Veronica M H Tawhai. Weeping Waters: The Treaty of Waitangi and Constitutional Change [in English]. Wellington, NZ: Huia Publishers, 2010.

Mutu, Margaret State of Māori Rights. Wellington: Huia, 2011.

'Te Tiriti O Waitangi in a Future Constitution', 2013 Robinson Lecture, 2013.

Nairn, Raymond G and Timothy N McCreanor. 'Race Talk and Common Sense: Patterns in Pakeha Discourse on Maori/Pakeha Relations in New Zealand'. Journal of Language and Social Psychology 10, no. 4 (1991): 245-262.

Native Web. 'The Bull Inter Caetera (Alexander VI), May 4, 1493', http://www.nativeweb.org/pages/legal/indig-intercaetera.html.

Nepolean, Val. 'Recovering Indigenous Legal Systems \& Governance'. In Singing a New Song. Victoria, BC: YouTube, 2013. Conference Paper accessed 17 November 2014, https://www.youtube.com/watch?v=gd2NYIfDXoO

New Zealand History. 'The 1835 Declaration of Independence', Ministry of Culture and Heritage, http://www.nzhistory.net.nz/media/interactive/thedeclaration-of-independence.

One News. 'Not All Smooth Sailing for John Key at Waitangi', TVNZ, 2015. 
Orange, Claudia. The Treaty of Waitangi. Bridget Williams Books, 2011. Otago Daily Times, 'NZ's "Clean Environment" under Pressure', Otago Daily Times, 2015.

Parata $v$. Bishop of Wellington (1877) 3 NZ Jur (NS) (Supreme Court).

Patterson, Jane. 'Spat over Maori Sovereignty Versus Separatism', Radio New Zealand, 10 February 2015, accessed 7 Ocbober 2015, http://www.radionz.co.nz/news/political/265682/spat-overmaori-sovereignty-versus-separatism.

Pihama, Leonie. 'A Conversation About Kaupapa Māori Theory and Research', paper presented at the Kei Tua o te Pae Hui Wellington, 2011.

_ 'Kaupapa Māori Theory: Transforming Theory in Aotearoa'. He Pukenga Korero 9, no. 2 (2012).

Porter, Libby. 'Planning in (Post)Colonial Settings: Challenges for Theory and Practice'. Planning Theory \& Practice 7, no. 4 (2006): 383396.

- Unlearning the Colonial Cultures of Planning [in English] (Burlington, VT: Ashgate, 2010).

Puhiwāhine. He Waiata Aroha Mo Te Toko Māhuta (Ka Eke Ki Wairaka). Owairaka: Ngāti Tūwharetoa, n.d.

Quality Planning, 'The RMA Quality Planning Resource: Consultation with Tangata Whenua,', accessed 10 December 2015, http://www.qualityplanning.org.nz/index.php/supportingcomponents/consultation/consulting-with-tangata-whenua.

Quilliam, Adam and Bennett, Rebecca. 'Crown Still in Charge: Minister Chris Finlayson on Waitangi Treaty Ruling', New Zealand Herald, 2014.

Radio New Zealand. Does NZ have a problem with anti-Maori racism? Radio New Zealand: Checkpoint with John Campbell.

Wellington: Radio New Zealand, 9 May 2016. Accessed 18 June 2016. Radio New Zealand, 'New Plymouth councillors leave Parihaka hīkoi', Radio New Zealand: Checkpoint with John Campbell. Wellington: Radio New Zealand. 17 June 2016, accessed 18 June 2016.

https://www.youtube.com/watch?v=Kh1 nyb7UKRM.

'New Plymouth councillors leave Parihaka hīkoi'. Radio New Zealand: Checkpoint with John Campbell. Wellington: Radio New Zealand. 17 June 2016. Accessed 18 June 2016. http://www.radionz.co.nz/national/programmes/checkpoint /audio/201804958/new-plymouth-councillors-leaveparihaka-hikoi.

'Tuwharetoa's big losses a familiar story - top lawyer', Radio New Zealand: Checkpoint with John Campbell. Wellington: Radio New Zealand. 17 June 2016, accessed 20 June 2016.

http://www.radionz.co.nz/national/programmes/checkpoint/audio/20164365/tuwharetoa's-biglosses-a-familiar-story-top-lawyer.

$R v$. Symonds (1847) NZPCC 387 (Supreme Court). 
Rangihau, John. 'Being Maori'. In Te Ao Hurihuri: The World Moves On, edited by Micheal King. Auckland: Longman Paul, 1977.

Reus-Smit, Christian. Individual Rights and the Making of the International System. Cambridge, UK: Cambridge University Press, 2013.

Riley, Murdoch. Māori Sayings and Proverbs. Paraparaumu: Viking Sevenseas, 1990.

Ritchie, James. 'Working in the Maaori World'. In Resource Papers: A Working Paper Series. Hamilton: Centre for Māori Studies, 1989.

Roberts, Mere, Waerete Norman, Nganeko Minhinnick, Del Wihongi and Carmen Kirkwood. 'Kaitiakitanga: Maori Perspectives on Conservation'. Pacific Conservation Biology 2, no. 1 (1995): 720.

Schulte-Tenckhoff, Isabelle. 'Treaties, Peoplehood, and SelfDetermination: Understanding the Language of Indigenous Rights'. In Indigenous Rights in the Age of the UN Declaration, edited by Elvira Pulitano, 65-86. West Nyack, NY: Cambridge University Press, 2012.

Simon, Hemopereki. 'Me Haka I Te Haka a Tānerore?: Māori "Post-War" Culture and the Place of Haka in Commemoration at Gallipoli'. Australasian Canadian Studies (forthcoming).

'He Mahi Whakamanakore: Destruction of Indigenous Heritage Sites at Otuparae: A Case Study of the Otuparae Headland Development'. Master of Philosophy Thesis, Massey University, 2011.

Simon, Katarina. 'Finding Synergistic Conservation Values?: Māori Tikanga, Science, Resource Management, and the Law'. PhD thesis, University of Waikato, 2007.

Statistics New Zealand. 'Ngāti Tūwharetoa', author, http://www.stats.govt.nz/Census/2013-census/profile-andsummary-reports/iwi-profiles-

individual.aspx?request_value $=245698$ tabname $=$ Populationa ndgeography

Stevenson, Marc 'The Possibility of Difference: Rethinking CoManagement'. Human Organization 65, no. 2 (2006): 167-180.

Te Heuheu v. Aotea District Mãori Land Board [1941] NZLR 590; [1941] AC 308 (Privy Council).

Te Kawariki and Network Waitangi. Ngāpuhi Speaks: Independent Report on Ngāpuhi Nui Initial Inquiry into He Wakaputanga and Te Tiriti $O$ Waitangi [in English]. Kaitaia: Te Kawariki and Network Waitangi Whāngārei Inc, 2012.

Toesing, Gale (2012). 'Global Indigenous Womens' Caucus Probes

Doctrine of Discovery's Impact on Women',

Indiancountrytodaymedianetwork.com, 05 September, accessed 9 November 2015, http://indiancountrytodaymedianetwork.com/2012/05/09/ global-indigenous-womens-caucus-probes-doctrinediscoverys-impact-women-111765. 
Tomlins, Christopher. 'The Legal Cartography of Colonization, the Legal Polyphony of Settlement: English Intrusions on the American Mainland in the Seventeenth Century'. Law \& Social Inquiry 26, no. 2 (2001): 315-372.

TPK. 'Te Arawa Waka: Ngāti Tūwharetoa'. TPK, accessed April 12, 2016. http://www.tkm.govt.nz/iwi/ngati-tuwharetoa/ (n.d.).

Trinder, Joe. 'Colonisation Is Not Settlement', mananews.co.nz, 2014.

United Nations. 'The Declaration on the Rights of Indigenous Peoples', United Nations, http://www.un.org/esa/socdev/unpfii/documents/DRIPS_e n.pdf.

Vardoulakis, Dimitris. "We will decide who comes to this country": Law, Justice and the three Faces of Sovereignty'. LIRC 2013 Seminar Series. Wollongong, NSW: University of Wollongong, 11 September 2013.

Waitangi Tribunal. 'The English Version of the Treaty of Waitangi', http://www.justice.govt.nz/tribunals/waitangitribunal/treaty-of-waitangi/the-english-version-of-the-treatyof-waitangi.

'He Whakaputanga Me Te Tiriti: The Declaration and the Treaty: The Report on Stage 1 of the Te Paparahi O Te Raki Inquiry'. Lower Hutt, New Zealand: Legislation Direct, 2014.

'The Kawharu Translation'. Waitangi Tribunal, http://www.justice.govt.nz/tribunals/waitangitribunal/treaty-of-waitangi/the-kawharu-translation.

'The Māori Version of the Treaty of Waitangi'. Waitangi Tribunal, http://www.justice.govt.nz/tribunals/waitangi-

tribunal/treaty-of-waitangi/the-maori-version-of-the-treatyof-waitangi.

'The Principles of the Treaty'. Waitangi Tribunal, http://www.justice.govt.nz/tribunals/waitangitribunal/treaty-of-waitangi/the-principles-of-the-treaty.

Wakefield, Edward Jerningham. Adventure in New Zealand. Christchurch: Whitcombe and Tombs, 1955.

Walker, Ranginui. Ka Whawhai Tonu Matou [in English]. Auckland; New York: Penguin Books, 2004.

Watkins, Tracy. 'NZ Does U-Turn on Rights Charter', stuff.co.nz, 20 April 2010, available from http://www.stuff.co.nz/national/politics/3599153/NZ-doesU-turn-on-rights-charter, accessed 9 November 2015.

Williams, Brackette F. Women out of Place: The Gender of Agency and the Race of Nationality. New York: Routledge, 1996.

Williams, David. A Simple Nullity?: The Wi Parata Case in New Zealand Law and History [in English]. Auckland, NZ: Auckland University Press, 2011.

Williams, Joe. 'The Māori Land Court-A Separate Legal System?'. Occasional Paper No 4 (2001).

Wright, Matthew. Shattered Glory: The New Zealand Experience at Gallipoli and the Western Front. Auckland: Penguin, 2010. 


\section{Notes}

$1 \quad$ Murdoch Riley, Māori Sayings and Proverbs (Paraparaumu: Viking Sevenseas, 1990), 5 (Quote:1-6); Kingi Ihaka, 'Proverbial and Popular Sayings of the Māori: Nga Whakatauki me Ngā Pepeha Maori,' Te Ao Hou 18 (May 1957), http://teaohou.natlib.govt.nz/journals/teaohou/issue/Mao18TeA Lc20.html This whakatauki is also associated with the Māori spiritual and resistence leader Te Whiti o Rongomai position on colonisation.

2 For the purposes of this paper, Te Reo Māori is the indigenous language of New Zealand. It will not be treated as a foreign language and italicised as is normal practice with Chicago $16^{\text {th }}$ edition style. Translations will be provided in the glossary. Where quotations are used with translations provided by others, these will be incorporated into the quotation. In all cases where it is necessary to convey Māori cultural understandings, Te Reo Māori (Māori language) words will be privileged over English.

3 Self-determination.

4 The use of the term 'Māori' in this article is interchangable with the old colonial spelling as being 'Maori' where it is used in original text by other authors as quotes.

5 Clan, sub-group.

6 Indigenous nation.

7 White or European person or people.

8 Customary territory of a hapu or iwi. The New Zealand government acknowledges that Tūwharetoa was an iwi invaded by colonial forces in pursuit of Te Kooti Arikirangi. This was the excuse used by the colonial government to occupy Tūwharetoa.

9 Authority, power, ownership, status, influence, dignity and respect derived from the atua.

10 The Treaty of Waitangi (English version) and Te Tiriti o Waitangi (Te Reo Māori version) are accepted as two very different documents, due to their content and understandings. For more information, refer to Ani Mikaere, 'Te Tiriti and the Treaty: Seeking to Reconcile the Irreconcilable in the Name of Truth', in He Rukuruku Whakaaro: Colonising Myths Mãori Realities (Wellington: Huia, 2011), 123-146.

11 Indigenous autonomous power is similar to the concept of sovereignty. The author would like the article to be read in its entirety to understand this concept fully.

12 The research completed in this article is written as a form of Kaupapa Māori Research. To maintain brevity in this article, I refer the reader to information on Kaupapa Māori research by Ella Henry and Hone Pene, 'Kaupapa Māori: Locating Indigenous Ontology, Epistemology and Methodology in the Academy', Organization 8, no. 
2 (2001); Leonie Pihama, 'A Conversation About Kaupapa Māori Theory and Research' (paper presented at the Kei Tua o te Pae Hui Wellington, 2011); Leonie Pihama, 'Kaupapa Māori Theory: Transforming Theory in Aotearoa', He Pukenga Korero 9, no. 2 (2012). For the purposes of validity, forms of group validation have been used in the development of this article. This was done by checking what was being written with members of Tūwharetoa via multiple methods. This paper could also be considered a form of critical Indigenous philosophy. Lastly, the author acknowledges the existence of other forms of patriarchal sovereignty, particularly in Te Ao Māori. However, for the purposes of brevity and to cover the topic with the respect that it deserves the author believes that this topic requires its own journal article. The author also views this approach as valid as the main focus of this article is on central government and hapū/iwi relations.

13 TPK, 'Te Kahui Mangai: Ngati Tuwharetoa,' Accessed April 12, 2016. http://www.tkm.govt.nz/iwi/ngati-tuwharetoa/

14 Puhiwāhine, He Waiata Aroha Mo Te Toko Māhuta (Ka Eke Ki Wairaka). (Owairaka: Ngāti Tūwharetoa, nd).

'Ngāti Tūwharetoa', Statistics New Zealand, http://www.stats.govt.nz/Census/2013-census/profile-andsummary-reports/iwi-profilesindividual.aspx?request value $=24569 \&$ tabname $=$ Populationandge ography. This does not include uri (descendants) of the iwi that live elsewhere in the world, in particular Australia.

16 New Zealand Māori Council v. Attorney-General. The principles are generally considered to be protection, participation, partnership. For more commentary on this please refer to Mere Roberts et al., 'Kaitiakitanga: Maori Perspectives on Conservation', Pacific Conservation Biology 2, no. 1 (1995); Merata Kawharu, 'Kaitiakitanga: A Māori Antropological Perspective of the Māori Socio-Environmental Ethic of Resource Management,' The Journal of The Polynesian Society 109, no.4 (2000), 350-351; 'The Principles of the Treaty', Waitangi Tribunal, http://www.justice.govt.nz/tribunals/waitangi-tribunal/treaty-ofwaitangi/the-principles-of-the-treaty, accessed 29 December 2015. This is a distinctly planners way of explaining the Principles of the Treaty. However, in practice, under the RMA it is provided for through things like the inclusion of clauses in the legislation urging planners to provide for kaitiakitanga.

17 For the text of the declaration, refer to 'The Declaration on the Rights of Indigenous Peoples', United Nations, http://www.un.org/esa/socdev/unpfii/documents/DRIPS_en.pdf , accessed 29 December 2015.

18 Indigenous nation.

19 The Treaty of Waitangi (English version) and Te Tiriti o Waitangi (Te Reo Māori version) are accepted to be two very different documents, 
due to their content and understandings. For more information, refer to Ani Mikaere, 'Te Tiriti and the Treaty', 123-146. He Whakaputanga is also refered to as The Declaration of Independence in English is an important constitutional document that led to the eventual creation of Te Tiriti

20 Representatives of The British Crown, 'Te Tiriti O Waitangi', (Waitangi 1840).

21 Representatives of The British Crown, 'The Treaty of Waitangi', (Waitangi 1840).

22 James Ritchie, 'Working in the Maaori World', in Resource Papers: A Working Paper Series (Hamilton: Centre for Māori Studies, 1989).

23 Schulte-Tenckhoff, Isabelle. 'Treaties, Peoplehood, and SelfDetermination: Understanding the Language of Indigenous Rights'. In Indigenous Rights in the Age of the UN Declaration, edited by Elvira Pulitano, 65-86. West Nyack, NY: Cambridge University Press, 2012, 65.

24 John Rangihau, 'Being Maori', in Te Ao Hurihuri: The World Moves On, ed. Micheal King (Auckland: Longman Paul, 1977).

25 Hirini Matunga, 'Decolonising Planning: The Treaty of Waitangi, the Environment and a Dual Planning Tradition', in Environmental Planning in New Zealand, ed. Ali Perkins and Harvey Memon (Palmerston North: Dunmore Press, 1993), 36.

26 Katarina Simon, 'Finding Synergistic Conservation Values?: Māori Tikanga, Science, Resource Management, and the Law' (PhD, University of Waikato, 2007), vii.

27 Ministry for the Environment and Ministry for Agriculture and Forestry, 'Wai Ora: Report of the Sustainable Water Programme Action Consultation Hui', ed. Ministry for the Environment and Ministry for Agriculture and Forestry (Wellington: Government Printer, 2005).

28 Traditional knowledge.

29 Awatere et al., 'Kaitiakitanga O Ngā Ngāhere Pōhatu: Kaitiakitanga of Urban Settlements', in Ryan Walker, Ted Jojola and David Natcher. eds., Reclaiming Indigenous Planning, (Montreal: McGillQueen's University Press, 2013), 237; Marc Stevenson, 'The Possibility of Difference: Rethinking Co-Management', Human Organization 65, no. 2 (2006), 167-169.

30 Gathering or meeting.

31 Indigenous nation.

32 Ministry for the Environment and Ministry for Agriculture and Forestry, Wai Ora, 'Report of the Sustainable Water Programme Action Consultation Hui' (Wellington, 2005), 6.

33 Indigenous nation.

34 A tikanga concept of the home fires burning. However in this context, it refers to those who undertake that activity by being 
resident on ancestral land. Refer to Ngāneko Minhinnick, Establishing Kaitiaki. Research report prepared for Auckland Local Government (Auckland, 1988).

Indigenous nation boundry or area. Refer to Richard Benton, Alex Frame and Paul Meredith, eds. Te Mātāpunenga: A Compendium of References to the Concepts and Institutions of Māori Customary Law (Wellington: VUW Press, 2013), 105.

36 Kirsten Hagen, 'Māori Interests in Natural Resource Management: 2012 in Review,' Māori Law Review 3

(March 2013), http://maorilawreview.co.nz/2013/03/maoriinterests-in-natural-resource-management-2012-in-review.

37 Hagen, 'Maori Interests'; Quality Planning, 'The RMA Quality Planning Resource: Consultation with Tangata Whenua,', accessed 10 December 2015 ,

http://www.qualityplanning.org.nz/index.php/supportingcomponents/consultation/consulting-with-tangata-whenua.

38 Merata Kawharu, 'Kaitiakitanga: A Māori Anthropological Perspective of the Māori Socio-Environmental Ethic of Resource Management,' Journal of the Polynesian Society 109 no.4 (2000): 349-370.

39 Awatere et al., 'Kaitiakitanga o Ngā Ngāhere Pōhatu,' 236; Marc Stevenson, 'The Possibility of Difference: Rethinking Comanagement,' Human Organization 65 no.1 (2006).

40 Aileen Moreton-Robinson, 'The House That Jack Built: Britishness and White Possession', Australian Critical Race and Whiteness Studies Association Journal 1, no. 1 (2005).

41 Gale Toesing, 'Global Indigenous Womens' Caucus Probes Doctrine of Discovery's Impact on Women', Indiancountrytodaymedianetwork.com 5 September 2012, available from http://indiancountrytodaymedianetwork.com/2012/05/09/globa 1-indigenous-womens-caucus-probes-doctrine-discoverys-impactwomen-111765, accessed 9 November 2015.

42 Robert J Miller and Elizabeth Furse, Native America, Discovered and Conquered: Thomas Jefferson, Lewis \& Clark, and Manifest Destiny (Westport, CT: Praeger Publishers, 2006); Robert J Miller, Discovering Indigenous Lands: The Doctrine of Discovery in the English Colonies (Oxford: Oxford University Press, 2010).

43 R v. Symonds (1847) NZPCC at 388.

44 Moana Jackson, 'The Culture of Colonisation' (Te Pūtahi-a-Toi (Māori Studies) Massey University, 2011). This is where the British built up knowledge and practices of engaging with Indigenous peoples over time. Jackson argues that the British were very skilled and experienced at colonising Indigenous peoples upon their arrival in Aotearoa New Zealand. They had built a culture based on their practices. 
45 For more on the concept of 'plante' and the historical philosophy behind British colonisation, refer to Christopher Tomlins, "The Legal Cartography of Colonization, the Legal Polyphony of Settlement: English Intrusions on the American Mainland in the Seventeenth Century', Law \& Social Inquiry 26, no. 2 (2001). Note that in the context of colonisation, to 'plante' means to transplant the European civilised society and norms upon the lands of Indigenous people.

46 White possessive theory is not a traditional theory as such. To explain it fully, the author has chosen to do so by extracting important ideas from the collective works of Moreton-Robinson.

47 Brodkin, 1999; Crenshaw et al., 1995; Cuomo and Hall, 1999; Delgado and Stefancic, 1997; Dyer, 1997; Flagg, 1998; Frankenberg, 1993; Haney Lopez, 1996; Harris, 1995; Hill, 1997; Levine-Rasky, 2002; Morrison, 1992; Rasmussen et al., 2001 as cited in Aileen Moreton-Robinson, 'Towards a New Research Agenda? Foucault, Whiteness and Indigenous Sovereignty', Journal of Sociology 42, no. 4 (2006).

48 Aileen Moreton-Robinson, The Possessive Logic of Patriarchal White Sovereignty: The High Court and the Yorta Yorta Decision', Borderlands e-journal 3, no. 2 (2004), http://www.borderlands.net.au/vol3no2_2004/moreton_possessi ve.htm. The term 'white patriarchal sovereignty' is an inherited term from the work of Aileen Moreton-Robinson. It first appears in this in this journal article in 2004. As explained above the source of patriarc

49 Val Nepolean, 'Recovering Indigenous Legal Systems \& Governance', in Singing a New Song Conference (Victoria, BC: YouTube, 2013). Conference Paper accessed 17 November 2014, https: / / www.youtube.com/watch?v=gd2NYIfDXoO.

50 Hemopereki Simon, 'Me Haka i Te Haka a Tānerore?: Māori "PostWar" Culture and the Place of Haka in Commemoration at Gallipoli', Australasian Candian Studies (forthcoming).

51 Mason Durie. 'Race and Ethnicity in Public Policy: Does It Work?' In The Social Policy, Research \& Evaluation Conference 2004, Wellington, 2004.

52 Mason Durie. 'Race and Ethnicity in Public Policy: Does It Work?; 'Hemopereki Simon, 'Me Haka i Te Haka a Tānerore?'

53 Aileen Moreton-Robinson, 'Virtuous Racila States: The Possessive Logic of Patriarchal White Sovereignty and the United Nations Declaration on the Rights of Indigenous Peoples', Griffith Law Review 20, no. 3 (2011).

54 Moreton-Robinson, 'The Possessive Logic of Patriarchal White Sovereignty'.

55 Aroha Mead, 'Ngā Tikanga, Ngā Taonga: Cultural and Intellectual Property: The Rights of Indigenous People', in University of Auckland, ed. The International Research Institute for Māori and Indigenous Education (Auckland, 1994). The Māori approach is 
highlighted in Italics while the Western approach appears as normal.

56 Ibid.

57 Carwyn Jones, 'A Māori Constitutional Tradition', paper presented at Unearthing New Zealand's

Constitutional Tradition Conference, Wellington, Aotearoa New Zealand, 28-29 August 2013), 2-3.

58 Māori Marsden, 'God, Man, and the Universe' in Micheal King, ed., Te Ao Hurihuri: The World Moves (Wellington: Hicks Smith, 1975), 145.

59 Margaret Mutu, State of Mãori Rights (Wellington: Huia, 2011), 213.

60 Indigenous sovereignty; a tikanga concept where the iwi or hapu have the authority and capacity to be autonomus, self-governing entities. There is a difference with mana whenua, which literally means power, authority, juristiction, influence, or governance over land or territory. Refer to Richard Benton, Alex Frame and Paul Meredith, eds. Te Mātāpunenga: A Compendium of References to the Concepts and Institutions of Māori Customary Law (Wellington: VUW Press, 2013), 175, 178. http: / / maoridictionary.co.nz/search?idiom $=\&$ phrase $=\&$ proverb $=\&$ $\begin{array}{lll}\text { loan}=\& \text { histLoanWords=\&keywords=motuhae, } & \text { accessed } & 17\end{array}$ December 2015.

62 'While the Fire Burns, the Mana is Effective' refer to Hirini Moko Mead and Neil Grove, 'Ngā Pepehā a Ngā Tìpuna, 2nd ed. (Wellington: Victoria University Wellington Press, 2001), 197.

63 Proverb.

64 The tikanga concept of the home fires burning. For more information, refer to Minhinnick, Establishing Kaitiaki.

65 Minhinnick, Establishing Kaitiaki.

66 Apirana Mahuika, 'A Ngāti Porou Perspective', in ed., Veronica Tāwhai and Katarina Gray-Sharp, Weeping Waters: The Treaty of Waitangi and Public Policy (Wellington: Huia, 2011), 148.

67 Lindsay Cox, Kotahitanga: The Search for Māori Political Unity (Auckland: Oxford University Press, 1993), 19.

68 Carwyn Jones, 'A Māori Constitutional Tradition', 1.

69 Te Kawariki and Network Waitangi, Ngäpuhi Speaks: Independent Report on Ngāpuhi Nui Initial Inquiry into He Wakaputanga and Te Tiriti $O$ Waitangi (Kaitaia: Te Kawariki and Network Waitangi Whangarei Inc, 2012).

70 Waitangi Tribunal, 'He Whakaputanga Me Te Tiriti: The Declaration and the Treaty: The Report on Stage 1 of the Te Paparahi O Te Raki Inquiry', (Lower Hutt, New Zealand: Legislation Direct, 2014); Jane Patterson, 'Spat over Maori Sovereignty Versus Separatism' (Radio New Zealand, 2015).

71 Tikanga concept of 'people of the land' indicates the Indigenous grouping with a traditional relationship with a defined area or 'rohe'. 
72 Tikanga concept of a place to stand, used to refer to a person who, through whakapapa and mana whenua, can belong and be connected to that place.

73 A person who undertakes a traditional role to guard or watch over tāonga (treasures) that belongs to the group. In this case, it refers to natural resources. Refer to Benton, Frame and Meredith, eds. Te Mātāpunenga, 105.

74 Minhinnick, Establishing Kaitiaki, 1.

75 Cox, Kotahitanga, 19.

76 Indigenous sub-nation, sub-tribe.

77 Durie, 'When Will the Settlers Settle?', 449; Edward Taihakurei Durie, 'Ancestral Laws of Māori', in Danny Keenan ed., Huia Histories of Maori: Ngā Tāhuhu Kōrero (Wellington: Huia, 2012), 10; Te Kawariki and Network Waitangi, Ngāpuhi Speaks.

78 Durie, 'When Will the Settlers Settle?', 449.

79 Indigenous sovereignty.

80 Ani Mikaere, 'Te Tiriti and the Treaty'; Hawkesley and Howson, 'Tino Rangatiratanga and Mana Motuhake', 246-257.

81 Charles Hawkesley and Richard Howson, 'Tino Rangatiratanga and Mana Motuhake', 246-257.

82 Chieftainship.

83 Paramount chieftainship.

84 Durie, 'Te Mana Te Kāwanatanga', 2.

85 Hawkesley and Howson, 'Tino Rangatiratanga and Mana Motuhake'.

86 Derek Coxton, 'The Peace of Westphalia: Of 1648 and the Origins of Sovereignty', The International History Review, (2010): 570.

87 F H Hinsley, 'The Concept of Sovereignty and the Relations between States', in ed. W J Stankiewicz, In Defense of Sovereignty (New York: Oxford University Press, 1969), 275.

88 Dimitris Vardoulakis, "We will decide who comes to this country": Law, Justice and the three Faces of Sovereignty', LIRC 2013 Seminar Series (Wollongong, NSW: University of Wollongong, 11 September 2013).

89 Greg Marks, 'Indigenous Peoples and Sovereignty', Australian Human Rights Commission Seminar Series (Canberra, ACT: Australian Human Rights Commission, 10 November 2004).

90 Māhuika, 'Ngāti Pōrou Perspective'. The idea of mana motuhake being the 'third mana' comes from the waiata tohutohu by Te Kooti Arikirangi called, 'Kāori Te Pō Nei e Mōrikarika Noa!' Prof. Taiarahia Black comments that, 'Ko tā Te Kooti whakahau kia mau ki te mana motuhake, kia noho tonu i tā te tikanga Māori. Taiarahia Black, 'He Mana Tō Te Waiata Tāwhito’ 181-196. In Matariki: A Monograph (Wellington: Te Mata o Te Tau/Massey University, 2011).

91 Haka (Ngeri), 'E ko te Tui!' Unknown, Waikato (Kingitanga), circa 1860 s.

92 For more information on the Māori King Movement or Kīngitanga, refer to Michael King, Te Puea: A Life (Auckland: Reed, 2008); 
Kiingitanga, 'History', Kiingitanga, accessed 29 December 2015, http://www.kiingitanga.com/history/.

93 As cited in Māhuika, 'Ngāti Pōrou Perspective', 161. Interestingly, the line from this whakataukī, 'Ko tōku kīngitanga nō te pō mai ra anō' indicates that this form of mana is not only ancestral but goes back to the beginning of time. It reaffirms that mana motuhake is intergenerational and is handed down by whakapapa.

94 Refer to Edward Jerningham Wakefield, Adventure in New Zealand (Christchurch: Whitcombe and Tombs, 1955).

95 Te Kenehi Teira (Kaihautu Māori, Heritage New Zealand), Email Correspondence (14 June 2016). The hapu that received these whare carved by Motu Heta did so because of their support of Waikato-Tainui at the battle of Ōrakau, just outside of Kihikihi. Hoturoa maybe an exception to this.

96 Moreton-Robinson, 'Virtuous Racila States', 641.

97 Ibid.

98 Ibid.

99 Ibid.

100 Micheal Foucault, Society Must Be Defended (London: Penguin, 2003). As cited in Moreton-Robinson, 'Towards a New Research Agenda?', 383.

101 Matthew Wright, Shattered Glory: The New Zealand Experience at Gallipoli and the Western Front (Auckland: Penguin, 2010), 58.

Moreton-Robinson, 'Towards a New Research Agenda?' Journal of Sociology 42 no.4 (2006): 386, doi: 10.1177/1440783306069995. Moreton-Robinson, 'Virtuous Racila States', 647.

104 Cheryl Harris, 'Whiteness as Property', in Critical Race Theory: The Key Writings that Formed the Movement Kimberelé Crenshaw, Neil Gotanda, Gary Peller and Kendall Thomas, eds. (New York: The New Press, 1995). As cited in Aileen Moreton-Robinson, 'The Possessive Logic of Patriarchal White Sovereignty: The High Court and the Yorta Yorta Decision', Borderlands e-journal 3, no. 2 (2004); Moreton-Robinson, Aileen. 'Virtuous Racila States: The Possessive Logic of Patriarchal White Sovereignty and the United Nations Declaration on the Rights of Indigenous Peoples'. Griffith Law Review 20, no. 3 (2011).

105 Moreton-Robinson, The Possessive Logic of Patriarchal White Sovereignty'.

106 Watson, I. (2002) 'Aboriginal and the Sovereignty of Terra Nullius', Borderlands

1(2). (consulted July 2006): www.borderlandsejournal.adelaide.edu.au; Ta Alfred (2001) 'From Sovereignty to Freedom: Toward and Indigenous Political Discourse', Indigenous Affairs 3: 22-34. As cited in MoretonRobinson, 'Towards a New Research Agenda?' 384. 
107 Duncan Ivison, Paul Patton and Will. Sanders (eds) (2000) Political Theory and the Rights of Indigenous Peoples. Cambridge: Cambridge University Press, 384-385. As cited in Moreton-Robinson, 'Towards a New Research Agenda?' 384-385.

Larrisa Behrendt, (2003) Achieving Social Justice: Indigenous Rights and Australia's Future. Annandale: Federation Press. As cited in Moreton-Robinson, 'Towards a New Research Agenda?' 385. Aileen Moreton-Robinson, 'Towards a New Research Agenda? Foucault, Whiteness and Indigenous Sovereignty'.

110 Moreton-Robinson, 'Virtuous Racila States'.

111 Coxton, 'The Peace of Westphalia', 520.

112 The author suggests that the time has come to rename these as 'treaty settlement' does not convey the reality of the situation.

113 R v. Symonds, which incorporated the doctrine of discovery into New Zealand common law; Parata v. Bishop of Wellington, which held that the treaty was a mere nullity and sovereignty was signed over to the Crown; Te Heuheu v. Aotea District Māori Land Board, that held that the Treaty of Waitangi was a treaty of succession could only be administered as right if incorporated into municipal law; New Zealand Maori Council v. Attorney-General, which created and defined the treaty principles ignoring contra perferentem.

114 Refer to Christian Reus-Smit, Individual Rights and the Making of the International System (Cambridge, UK: Cambridge University Press, 2013), 120-23; Luke Glanville, Sovereignty and the Responsibility to Protect: A New History (London, UK: University of Chicago Press, 2014), 37-40.

Johnson v. McIntosh 21 (1823).

Coxton, 'The Peace of Westphalia'.

Moreton-Robinson, 'Virtuous Racila States'.

Refer to Libby Porter, Unlearning the Colonial Cultures of Planning (Burlington, VT: Ashgate 2010); Libby Porter, 'Planning in (Post)Colonial Settings: Challenges for Theory and Practice', Planning Theory \& Practice 7, no. 4 (2006): 383-396.

119 This is supported by the negative results released recently by Environment Aotearoa New Zealand 2015. For a copy of the report refer to Ministry for the Environment, Environment Aotearoa New Zealand 2015 , http://www.mfe.govt.nz/publications/environmentalreporting/environment-aotearoa-2015.

120 Kelly Mihaka, 'Tuhoe Can Do Better Job: Curtis', The Daily Post, 19 November 2015, http://www.nzherald.co.nz/rotorua-dailypost/news /news/article.cfm?c_id=1503437\&objectid=11547735.

121 Professional experience.

122 The author acknowledges that Matunga's work is based on the notion of bi-culturalism. There is a gap in the literature about the interaction between bi-culturalism and mana motuhake. However, due to word limit constraints and the need to remain concise, the author will address this later in another paper in this series. 
Michael Gunder and Clare Mouat, 'Symbolic Violence and Victimization in Planning Processes: A Reconnoitre of the New Zealand Resource Management Act', Planning Theory 1, no. 2 (2002).

124 Chris Bramwell, “Peaceful Settlement” View Challenged' (Radio New Zealand, 2015), accessed 28 December 2015, http://www.radionz.co.nz/news/political/260174/'peacefulsettlement'-view-challenged.

http://www.nzherald.co.nz/nz/news/article.cfm?c_id=1\&objectid $=11358560$, accessed 28 December 2015; 3 News, 'Waitangi Tribunal: Northland Maori Didn't Cede Sovereignty', (Mediaworks, 2014), accessed 28 December 2015, http://www.3news.co.nz/nznews/waitangi-tribunal-northlandmaori-didnt-cede-sovereignty-2014111413-ixzz3uwY8Fg5I. For a reaction to the Te Paparahi o Te Raki Report findings from The Waitangi Tribunal by Prime Minister John Key, refer to One News, 'Not All Smooth Sailing for John Key at Waitangi', (TVNZ, 2015), accessed 28 December 2015, https://www.tvnz.co.nz/onenews/archive/not-all-smooth-sailing-for-john-key-at-waitangi6228424; Joe Trinder, 'Colonisation Is Not Settlement', (mananews.co.nz, 2014), accessed 28 December 2015. http://mananews.co.nz/wp/?p=652. Ibid.

127 Robyn Anderson, 'Tōngariro National Park: An Overview Report on the Relationship between Māori and the Crown in the Establishment of the Tongariro National Park' (Wellington: The Crown Forestry Rental Trust, 2005); Simon, 'He Mahi Whakamanakore: Destruction of Indigenous Heritage Sites at Otuparae: A Case Study of the Otuparae Headland Development' (MPhil, Massey University, 2011).

128 Simon, 'He Mahi Whakamanakore'; Robyn Anderson, 'Tōngariro National Park: An Overview Report on the Relationship between Māori and the Crown in the Establishment of the Tongariro National Park'.

Ibid.

130 This is contradictory to what the traditional role is about. This description about is actually the role of kaumātua.

131 A lot of iwi members will argue that this has been a frequent feature of the processes pursued by the Tūwharetoa Hapū Forum where concerns raised by Te Hikuwai hapu that in the process have led to continued problems and have the potential to be a huge catalyst for future problems. This is because their concerns are routinely ignore and/or sidelined. 
132 Radio New Zealand, 'Tuwharetoa's big losses a familiar story - top lawyer', Radio New Zealand: Checkpoint with John Campbell, 17 June 2016, accessed 20 June 2016. http://www.radionz.co.nz/national/programmes/checkpoi nt/audio/20164365/tuwharetoa's-big-losses-a-familiar-story-toplawyer.The author believes that this would make a very good case study in governance for a doctoral study. Some suggested research questions could be: How did the personal relationships to the Arikitanga influence the spending of this money? Why did the settlement trust not have the right people in place? Is it ethical for governance entities to be spending $\$ 230,000+$ on prefabricated marae ablutions blocks? Most importantly what role did Dixon Chapman (the trust secretariat manager) play in the expenditure of these funds? Are the current set of trustees the best suited for these positions and what are their ties to the Arikitanga? Should those who played a role in the investment of the Mangamāwhitiwhiti block still be prosecuted? Should we as an iwi have bailed out this already failed land deal tied to Ngāti Tūrangitukua? Is there an historical trend of this unethical or 'dodgy' happenings in Tūwharetoa? Was it ethical for the Ariki to be occupying two positions (Ariki and Settlement Trust Chairperson)? Does democracy truly serve us in a post-settlement environment? In light of these questions: what does/should accountability in modern times look like in Tūwharetoa?

133 The meaning of this term will be further explored in this series of papers at a later date.

134 Refer to Mead, 'Ngā Tikanga, Ngā Taonga: Cultural and Intellectual Property: The Rights of Indigenous People', in The International Research Institute for Maori and Indigenous Education, ed., University of Auckland (Auckland, 1994).

135 This is an adaptation of Aroha Mead's Difference in Approaches Theory. Refer to Mead, 'Ngā Tikanga, Ngā Taonga: Cultural and Intellectual Property: The Rights of Indigenous People'

136 This is an adaptation of Aroha Mead's Difference in Approaches Theory, ibid.

137 Ministry for the Environment and Statistics New Zealand, 'Environment Aotearoa New Zealand', ed., Ministry for the Environment and Statistics New Zealand (Wellington: Government Printer, 2015); 'NZ's "Clean Environment" under Pressure', Otago Daily Times 2015, accessed 28 December 2015, http://www.odt.co.nz/news/national/360247/nzs-cleanenvironment-under-pressure.

138 Refer to Appendix 1. The decisions made by the then Native Land Court confirm this.

139 LNG is an acrynom from treaty settlement dealing which stands for Large Natural Grouping.

140 Refer to Raymond G Nairn and Timothy N McCreanor, 'Race Talk and Common Sense: Patterns in Pakeha Discourse on 
Maori/Pakeha Relations in New Zealand', Journal of Language and Social Psychology 10, no. 4 (1991); Michael King, The Penguin History of New Zealand (Auckland, NZ: Penguin Books, 2003), 569; Brackette F Williams, Women out of Place: The Gender of Agency and the Race of Nationality (New York: Routledge, 1996), 120; Ranginui Walker, Ka Whawhai Tonu Matou (Auckland; New York: Penguin Books, 2004), 225.

141 The author provided Prof. Paul Moon with a with a right of reply about the New Zeland Hearld statement just before publication. His comments in reply are as follows, "What I said about the 2014 Tribunal Report on what was known as the Sovereignty claim was that it was wrong in one crucial area. I pointed out that at the time the Treaty was signed, the British had no intention to extend their sovereignty over Maori. This was something that was done by stealth afterwards. According to British policy in early 1840, Maori sovereignty was guaranteed and British sovereignty was limited explicitly to 'Anglo-Saxons' living in the country. There are several documents which confirm this, and not one British Govt. document prior to 1840 which states the British wished to rule Maori. That changed, of course, after the Treaty was signed. This was misreported by the media.' Paul Moon, Email Corrospondence (14 June, 2016).

Radio New Zealand, 'Does NZ have a problem with anti-Maori racism?', Radio New Zealand: Checkpoint with John Campbell, 9 May 2016, accessed 18 June 2016. https://www.youtube.com/watch?v=Kh1 nyb7UKRM.

Radio New Zealand, 'New Plymouth councillors leave Parihaka hīkoi', Radio New Zealand: Checkpoint with John Campbell, 17 June 2016, accessed 18 June 2016. http://www.radionz.co.nz/national/programmes/checkpoint/aud io/201804958/new-plymouth-councillors-leave-parihaka-hikoi. Simon, 'Me Haka i Te Haka a Tānerore?' Ibid.

Manuka Henare, 'Te Tangata, Te Taonga, Te Hau: Māori Concepts of Property', paper presented at the Conference on Property and the Constitution, Wellington, 1998. Moana Jackson (n.d.) Facebook video, viewed 10 October, 2015, https://www.facebook.com/sina.browndavis/videos/4725430593 $\underline{2} /$.

148 Robert Nesta 'Bob' Marley ('Bob Marley and The Wailers'), Redemption Songs [lyric] Uprising (Kingston, Jamaica: Island/Tuff Gong: 1980).

149 Sidney M Mead, Neil Grove and Maori Studies Victoria University of Wellington, Dept. of Maori, Ngā Pepeha a Nga Tūpuna (Wellington, NZ: Dept. of Maori Studies, Victoria University of Wellington, 1994).

150 Ibid. 